\title{
Physical controls and mesoscale variability in the Labrador Sea spring phyto- plankton bloom observed by Seaglider
}

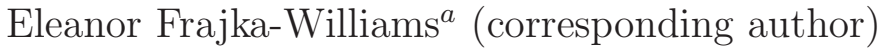 \\ eleanor@ocean.washington.edu \\ Peter B. Rhines ${ }^{a}$, \\ rhines@ocean.washington.edu \\ Charles C. Eriksen ${ }^{a}$ \\ eriksen@u.washington.edu \\ ${ }^{a}$ School of Oceanography, University of Washington \\ Box 357940 \\ Seattle, WA 98105, USA
}

\begin{abstract}
We investigate the 2005 spring phytoplankton bloom in the Labrador Sea using a Seaglider equipped with hydrographic, bio-optical and oxygen sensors. The Labrador Sea blooms in distinct phases, two of which were observed by Seaglider: the north bloom and the central Labrador Sea bloom. The dominant north bloom and subsequent zooplankton growth is enabled by the advection of low-salinity water from West Greenland in the strong and eddy-rich separation of the boundary current. The glider observed high fluorescence and oxygen supersaturation within halinestratified lenses; higher fluorescence was observed between than within the fresh lenses. In the central Labrador Sea, the bloom occurred in thermally-stratified water. Two regions with elevated subsurface chlorophyll were also observed: a $5 \mathrm{~m}$ thin layer in the southwest Labrador Current, and within the front at the Labrador shelf break. The thin layer observations were consistent with vertical shearing of an initially thicker chlorophyll patch. Observations at the front showed high fluorescence down to $100 \mathrm{~m}$ depth and aligned with the isopycnals defining the front. The high resolution Seaglider sampling across the entire Labrador Sea provides first estimates of the scale dependence of coincident biological and physical variables.
\end{abstract}




\section{Introduction}

Seaglider transects of the Labrador Sea have established that advection of a low-salinity cap in the separation of the subpolar gyre from the West Greenland boundary current exerts strong control over deep convection, and hence over deep water production (Eriksen and Rhines, 2008). Here, and in an accompanying paper (Frajka-Williams and Rhines, 2008), we argue that the same freshwater cap controls the dominant phytoplankton and zooplankton production of the western subpolar Atlantic. With global warming increasing the supply of surface freshwater, both physical circulation and biological productivity of the region are likely to be affected.

The Labrador Sea is the western end of the subpolar gyre of the North Atlantic (Fig. 1a), and the biological system there is subject to nutrient replenishment by some of the deepest mixing in the northern hemisphere, as well as potential influences of mesoscale processes. The general circulation within the Labrador Sea is cyclonic, characterized by doming isopycnals and layers of distinct watermasses in the boundary currents. The surface of the boundary currents and the shelves are capped with very fresh, very cold water of Arctic origins. Extending from 200 to $800 \mathrm{~m}$ deep, encircling the Labrador Sea, is warm, saline Irminger Sea Water of subtropical origin. Labrador Sea Water formed during deep convection fills the central Labrador Sea from near the surface to $2500 \mathrm{~m}$ depth. Farther below lie Northeast Atlantic Deep Water and Denmark Strait Overflow Water which, together with Labrador Sea Water, make up North Atlantic Deep Water. Boundary currents are concentrated at the slope on the Greenland and Labrador sides, and offshore advection around the northern edge of the Labrador basin occurs in two or more diffuse branches (Fig. 1b). The deep waters are forced offshore by the shoaling topography, near the $3000 \mathrm{~m}$ isobath. This boundary current separation is visible as an eddy-kinetic-energy maximum (Fig. 1b). Further outflow from the Greenland slope occurs near the $1000 \mathrm{~m}$ isobath. Within this offshore advection are found Irminger Rings, coherent mesoscale eddies which are characterized by the fresh shelf waters at the surface and Irminger Sea Water at intermediate depths. 
The 1997 spring bloom in the Labrador Sea was observed by Head et al. (2000) from shipboard observations. They found two distinct bloom regions: the north bloom, which had ended by their sampling period (May-June), and the central Labrador Sea bloom, which was actively blooming. Their study also found low surface nitrate concentrations after the north bloom ( $<3 \mu \mathrm{M}$ to $<1 \mu \mathrm{M}$ in places). They used their observations to relate the bloom to zooplankton activity, and found that the timing of life cycles of the most abundant copepod, Calanus finmarchicus, corresponded to the time of the peak bloom, and that the region with the highest copepod biomass was the north bloom area. Two other papers on Labrador Sea spring bloom focus on bloom timing, one using SeaWiFS ocean color and a numerical model (Wu et al., 2008) and the other using SeaWiFS and hydrography (Frajka-Williams and Rhines, 2008). These studies have the advantage of a long, daily time series (1998-2003 and 1998-2008), but lack in situ observations to make a direct connection with water column stratification or dynamics.

Recent studies in biophysical interactions have focused on nutrients available for new production (see review by Klein and Lapeyre, 2009). In particular, estimate of nutrient fluxes to the euphotic zone based on basin-wide upwelling and downwelling do not supply enough nutrients to support the observed productivity. A numerical study of mesoscale processes, e.g. eddies, increased the estimates of nutrient fluxes, but are still about $30 \%$ too low (McGillicuddy et al, 2003). High resolution observations of physical and biological quantities may help identify processes which influence productivity, perhaps by supplying the missing nutrients.

Several observational studies of mesoscale impacts on production have focused on the subtropical, oligotrophic zones. In these regions, observations clearly show the influence of an eddy on an otherwise non-productive ocean. While production in the subpolar gyres is primarily supported by nutrients upwelled during deep wintertime mixing, mesoscale processes are still active and potentially increase net primary productivity.

In this paper, we use the Seaglider, an autonomous underwater instrument with the 
capability to resolve mesoscale features in hydrography and bio-optics. Over 500 profiles of hydrography and bio-optics are available from the spring and summer of 2005 in the Labrador Sea (Fig. 1). We will show the influence of stratification and the Labrador Sea circulation, as well as small scale processes in three regions of the Labrador Sea, on the spring bloom and later productivity.

In $\S 2$, we detail the data calibration and methods used. In $\S 3$, we provide a brief description of basin-scale bloom patterns and hydrography, and compare the 2005 bloom to climatology. In $\S 4$, we detail the structure of biological and physical variables in four productive regions observed by Seaglider 16: in the north bloom, the central Labrador Sea, a thin layer in the Labrador shelf current and at the Labrador shelf-break front. Finally, we conclude in $\S 5$.

\section{Data sources \& processing}

\subsection{Seaglider}

The Seaglider is an autonomous underwater vehicle developed at the University of Washington and the Applied Physics Lab (Eriksen et al., 2001). It navigates using dead reckoning and Global Positioning System (GPS) locators, receives instructions and transmits data via the Iridium satellite system after each dive-climb cycle. Profiles are made to $1000 \mathrm{~m}$ depth with an approximately 1:3 vertical to horizontal slope. Relative to aspect ratios of physical features in the Labrador Sea (e.g. a $100 \mathrm{~m}$ mixed layer depth divided by a largest Rossby radius of 10 s of kilometers, or the related Prandtl ratio, $f / N$ where $f$ is the Coriolis frequency and $N$ the buoyancy frequency), a 1:3 slope is virtually vertical. The glider typically surfaces $6 \mathrm{~km}$ from where it began its dive. On its sawtooth trajectory, the glider samplespacing averages $3 \mathrm{~km}$, but nearer the surface and $1000 \mathrm{~m}$ turnaround points, sampling is irregular, ranging from 100s of meters to $6 \mathrm{~km}$. During a single dive-climb cycle, sampling is 
done at variable time intervals, ranging from approximately every $0.6 \mathrm{~m}$ in the top $150 \mathrm{~m}$, incrementally reducing to $2.4 \mathrm{~m}$ from $250-1000 \mathrm{~m}$.

In this observational program, 5 Seagliders were deployed between October 2003 and August 2005. Seaglider 16, the focus of this paper, was deployed 5 April 2005 from Nuuk, West Greenland $\left(64.2^{\circ} \mathrm{N}, 51.8^{\circ} \mathrm{W}\right.$, Fig. 1). Moving at approximately $20 \mathrm{~cm} \mathrm{~s}^{-1}$ and buffetted by eddies, it followed a westward track along $64^{\circ} \mathrm{N}$ and then $900 \mathrm{~km}$ south along $58^{\circ} \mathrm{W}$, reaching the Labrador shelf around 20 June (Fig. 1). Along this track, the Seaglider measured temperature and conductivity (Sea-Bird Electronics (SBE) custom sensor), pressure (Paine Corporation 211-75-710-05 1500PSIA), fluorescence and optical backscatter (WETlabs custom ECO-BB2F puck), and dissolved oxygen (SBE 43F Clark-type oxygen electrode). Depth-averaged horizontal velocities are calculated from Seaglider measurements, using a flight model based on Seaglider hydrodynamics and surface positions between two consecutive surfacings with typical error of about $1 \mathrm{cms}^{-1}$. Data calibration details are given below.

\subsubsection{Salinity}

To conserve power and extend the range of the Seaglider, the SBE conductivity cell is unpumped. Instead, the measurement relies on glider motion through the water to passively flush the conductivity cell. The rate of flushing depends on glider attitude and speed, which depends on buoyancy. We estimate this flushing speed based on the Seaglider flight model (Eriksen et al., 2001) and use it to apply thermal inertia corrections to the conductivity data according to Lueck (1990). Relaxation constants are determined by minimizing the along-isopycnal difference between salinities of successive climb-dive near the surface or diveclimb at depth. More comprehensive corrections are in development (Eriksen, in prep). This processing reduces differences in salinity, but due to uncertainty in the flight model and likely effects of small-scale turbulent motions around the glider sensors, it does not remove all spike 
and hysteresis artifacts. Remaining spikes are removed (salinities below 30 and above 36 psu) and resulting data are binned to $2 \mathrm{~m}$ resolution by interpolating to fine vertical resolution then using a median filter.

Potential density was then calculated using corrected salinities, in order to determine mixed layer depths. Density profiles were first smoothed with a boxcar moving window of $20 \mathrm{~m}$ depth. Mixed layer depths were calculated as the first depth where density in the $20 \mathrm{~m}$ bin exceeds the surface $20 \mathrm{~m}$ bin by at least $0.1 \mathrm{kgm}^{-3}$ (Lilly et al., 2003), an adequate threshold for the strong spring and summer pycnoclines in the Labrador Sea.

\subsubsection{Dissolved oxygen}

The oxygen electrode sensor has been known to drift with time and use (a decrease of 10-20 $\mu \mathrm{mol} \mathrm{L}^{-1}$ per 100 days (Nicholson et al., 2008)), and for this reason, is most often calibrated by comparing measurements to in situ bottle samples. The sensor used here was calibrated within 6 months of deployment, but oxygen concentrations were well below normal for this region-subsaturated by $30 \%$ instead of $6 \%$ as observed by Körtzinger et al. (2008). A repeat AR7w cruise was conducted nearby the glider measurements in space and time (Fig. 2a). We calibrated Seaglider 16 oxygen against their Winkler-calibrated CTD measurements, using 13 pairs of glider-AR7w profiles within $50 \mathrm{~km}$ and 2 weeks of each other (Fig. 2b-c). While these measurements were serendipitously close in space and time, estimates of oxygen decorrelation scales (described below in $\S 3$ ) are shorter than $50 \mathrm{~km}$ and blooms can peak and decline within 2 weeks. Natural variability in the AR7w oxygen profiles was $10-15 \mu \mathrm{molL}^{-1}$ and up to $30 \mu \mathrm{molL}^{-1}$ for gliders near at $300 \mathrm{~m}$. We calculated the root-mean-square error between calibrated Seaglider oxygen and AR7w data, for 6188 points of comparison, to be $15.6 \mu \mathrm{molL}^{-1}$. A second glider, Seaglider 15, travelled along nearly the same track as Seaglider 16 approximately 6 months earlier. In the absence of additional data available for calibration, and reasonable factory-calibrated measurements, 
we used factory-calibrated oxygen from Seaglider 15 to complete the annual cycle. Corrected data show surface saturation near equilibrium in the early spring, before the first observations of elevated fluorescence, which quickly reached supersaturation of $5-10 \%$ in regions with elevated fluorescence.

\subsubsection{Fluorescence and optical backscatter}

Fluorescence and optical backscatter are well known to relate to biological activity, though conversions between them to chlorophyll, phytoplankton biomass or other parameters of interest are complicated. Fluorescence $(F)$ is a proxy for the concentration of chlorophyll $a$, which fluoresces at $682 \mathrm{~nm}$. The Seaglider WETlabs puck actually excites chlorophyll using a blue LED and the red detector is near-infrared at $700 \mathrm{~nm}$, but wide enough to pick up fluorescence at $682 \mathrm{~nm}$ (Perry et al., 2008). Fluorescence measurements may be affected by photoacclimation, phytoplankton size, species assemblage, pigment composition and quenching (Sackmann et al., 2008). In the Labrador Sea, Lutz et al. (2003) found that the relationship between fluorescence and water sample estimates of chlorophyll changes over the course of a few months. Particulate optical backscatter, on the other hand, tends to correspond with phytoplankton biomass in the open ocean though it can respond to other substances as well (Fennel and Boss, 2003; Behrenfeld and Boss, 2003). The WETlabs puck measures scattering at red and blue wavelengths, 700 and $470 \mathrm{~nm}$ (particulate backscatter coefficients $b_{b p}(700)$ and $\left.b_{b p}(470)\right)$. For our purposes, we have converted fluorescence and optical backscatter volts into a "bloom intensity" index with units of chlorophyll concentration using an algorithm described below in $§ 2.2$. All figures and numbers in the text use $\mathrm{F}^{*}$ and $\mathrm{b}_{b p}{ }^{*}$, the bloom intensity index calculated from fluorescence and backscatter.

Seaglider estimates of fluorescence and backscatter correlate well (Fig. 3). One region where there is more spread in the scatter is near the surface (top $10 \mathrm{~m}$, Fig. 3a) in the Labrador slope region (squares). Here, the surface fluorescence to backscatter ratio varies 
much more than at 20-30 m (Fig. 3b). At depth (50-60 m, Fig. 3c), only the northern region (triangles) exhibits large values and the correlation is tight.)

This variability in the fluorescence to backscatter ratio $\left(\mathrm{F}: \mathrm{b}_{b p}\right)$ appears as a diurnal cycle in the surface layer (Fig. 4a). This is indicative of fluorescence quenching, a reduction in fluorescence quantum yield, often observed during the daytime (Sackmann et al., 2008). The vertical extent of quenching decreases with depth (Fig. 4b-c): backscatter is nearly uniform in the mixed layer, while fluorescence has a subsurface peak in the mixed layer which decreases nearer the surface. Quenching is reduced at depth due to light attenuation by water and particles (such as phytoplankton cells). The diurnal cycle is strongest in the surface layer, ranging from $\mathrm{F}: \mathrm{b}_{b p}$ peak-to-trough amplitude of $3 \mathrm{mg} \mathrm{m}^{-3}$ vs $1 \mathrm{mg} \mathrm{m}^{-3}$ at depth. The black filled hatched area is instantaneous PAR (iPAR), calculated as in Sackmann et al. (2008) so that the integral of each day's iPAR equals the daily value given by SeaWiFS satellites, by fitting a half-sine from sunrise to sunset. Maximal quenching in the Labrador slope region, that is, the lowest values of $\mathrm{F}: \mathrm{b}_{b p}$, occur on average $0.3 \mathrm{hrs}$ after the peak in iPAR. (On $1000 \mathrm{~m}$ deep dives, the Seaglider only surfaced every $\sim 8$ hrs so some aliasing is expected.) The ratios show quenching in the daytime surface by $70 \%$ relative to deep fluorescence to backscatter ratios, similar to values found by (Sackmann et al., 2008) off the Washington coast. Due to our confidence in surface backscatter correlating with fluorescence, we will use backscatter instead in regions where quenching is in effect.

\subsection{Satellite ocean color and Seaglider bloom intensity indices}

Though the Seaglider offers the strength of colocated physical and biological measurements, space-time aliasing can hinder interpretation of the data. We use satellite ocean color to place Seaglider data in the large-scale bloom patterns of the Labrador Sea. We used a daily, mapped $9 \mathrm{~km}$ resolution SeaWiFS chlorophyll-a product (Feldman and McClain, 2006). For visualization only, in Fig. 5, we used the merged SeaWiFS and MODIS (MODerate-resolution 
Imaging Spectrometer) product, at 8-day, $4 \mathrm{~km}$ resolution, which had better spatial coverage owing to the combination of data from two independent satellites.

Comparing SeaWiFS chlorophyll with in situ fluorescence, Perry et al. (2008) found that Seaglider fluorescence estimates of chlorophyll were three times as large as concurrent SeaWiFS estimates off the Washington coast. This is not altogether surprising since the SeaWiFS algorithm is still undergoing revision to make it more accurate regionally. Furthermore, SeaWiFS measurements are a spatial average over a pixel (here, $9 \mathrm{~km}$ by $9 \mathrm{~km}$ ) while Seaglider estimates are point measurements. Boss et al. (2008) found that APEX float measurements of fluorescence agreed well with satellite estimates over a 3 year period. While the relationship between in situ fluorescence and SeaWiFS chlorophyll is complicated and not yet fully resolved, we have used SeaWiFS chlorophyll to convert fluorescence to chlorophyll concentration. In the absence of bottle estimates of chlorophyll- $a$, we relate Seaglider fluorescence and optical backscatter to SeaWiFS chlorophyll by creating a bloom index of intensity. While this procedure does not guarantee quantitative accuracy, it makes possible direct comparisons between data sources.

To calculate the bloom intensity index, we averaged fluorescence and backscatter counts in the top $10 \mathrm{~m}$, and created a SeaWiFS time series of chlorophyll by averaging measurements within \pm 2 days and $\pm 0.5^{\circ}$ of each glider surface position. The methodology is similar to that in Sackmann (2007). We regressed the average backscatter against the SeaWiFS time series, and used the coefficients to convert backscatter counts into units of chlorophyll $\left[\mathrm{mg} \mathrm{m}^{-3}\right]$. The process for fluorescence was similar, except that we only compared SeaWiFS chlorophyll with fluorescence measurements made between $5 \mathrm{pm}$ and 5 am UTC, to reduce the effect of fluorescence quenching. We transform the full fluorescence and backscatter data sets similarly. 


\section{Basin-scale hydrography and productivity}

The Labrador Sea may be divided into distinct zones of hydrography and productivity. The north Labrador Sea (above $60^{\circ} \mathrm{N}$ and east of the Labrador shelf) has the earliest and most intense bloom. This region is also the site of the highest biomass of Calanus finmarchicus, the most abundant copepod in the region, and the location of the offshore-flowing branch of the West Greenland Current. The central Labrador Sea is a site of deep convection with wintertime mixed layer depths ranging from 1000 to $2500 \mathrm{~m}$ deep. The spring bloom here occurs after deep convection has ended. The Labrador shelves are ice-covered well into the spring, and have a quick ice-melt bloom followed by a second surface bloom. The Labrador Current, located on the shelf, is extremely fresh $(\mathrm{S}<32 \mathrm{psu})$ and divided from the central Labrador Sea by an intense shelf break front.

Seaglider 16 travelled over $2000 \mathrm{~km}$ from April to August, 2005, crossing the three zones at various stages in their annual cycles (Fig. 5) and also describing their hydrographic properties (Fig. 6). Labrador Sea climatological surface chlorophyll (row 1), 2005 surface chlorophyll (row 2) and glider timing relative to the local blooms (row 3) for occupation of the three zones are shown in Fig. 5. Seaglider 16 salinity, temperature, bottom depth, fluorescence and a time series of surface bloom intensity for the entire glider section are in Fig. 6. From this record, we see that north Labrador Sea hydrography is similar to deep West Greenland Current water, due to the offshore flow of freshwater from the deep boundary currents. This region has a fresh surface and warm, salty subsurface layer (Fig. 6: North). The central Labrador Sea bloom occurs in a warm layer above a deep homogenous layer (Fig. 6: central LS). The Labrador shelf is home to the Labrador shelf current and an intense shelf break front associated with a jet. The influence of these physical characteristics on productivity will be described further in later sections.

The 2005 spring and summer were different than climatology in that the north bloom was weaker than usual (Fig. 5a and d). The 2005 central Labrador Sea bloom and decline were similar in magnitude to climatology (Fig. 5b, c, e, f). The glider crossed through the 
north region during the local peak bloom and decline (see Fig. 5g). Continuing southward along $58^{\circ} \mathrm{W}$, it skirted the western edge of the central Labrador Sea region and encountered a secondary bloom near $58^{\circ} \mathrm{N}$ on the Labrador slope (Fig. 5h). During this time, it also crossed onto the Labrador shelf twice. On the shelf, it observed a thin, subsurface phytoplankton layer (Fig. 5c). Upon leaving the shelf a second time, the glider measured a persistent productive region at the Labrador shelf-break front after the local bloom had declined (Fig. 5i).

Glider bloom intensity in the top 20 m covaries with SeaWiFS surface chlorophyll (Fig. 6e) though Seaglider fluorescence is more variable, in part due to the spatial averaging intrinsic to SeaWiFS measurements. While bloom intensity shows that the north bloom was less intense than the central Labrador Sea bloom, depth-integrated chlorophyll estimates are similar between the two regions: $71.4 \pm 37.5 \mathrm{mg} \mathrm{m}^{-2}$ in the north, and $71.1 \pm 22.0 \mathrm{mg} \mathrm{m}^{-2}$ in the central Labrador Sea bloom. These compare well with in situ estimates by Cota et al. (2003) where they found integrated chlorophyll concentrations of $99 \pm 55 \mathrm{mg} \mathrm{m}^{-2}$ in May-June 1997, while wintertime values were $47 \pm 38 \mathrm{mg} \mathrm{m}^{-2}$.

Decorrelation length scales for mixed-layer average properties are all less than $100 \mathrm{~km}$, and closer to 5-20 km (Fig. 8a-c). The mixed layer concentrations of fluorescence and oxygen are very variable, while salinity and temperature have lower frequency/wavenumber changes (Fig. 8a). This is quantifiable by calculating autocorrelations for mixed layer properties, shown in Fig. 8b and c. The two regions shown here are the north bloom, from 400-650 km which is characterized by fresh lenses of $15-30 \mathrm{~km}$ scale (described in the next section) and the early central Labrador Sea bloom, which is in a relatively homogenous but gradually warming mixed layer. In both regions, biological variables (fluorescence and oxygen) decorrelate more rapidly than salinity and temperature. Contrasting the two regions, the north bloom temperature and salinity decay more quickly than the central Labrador Sea. This is a consequence of the glider passing through the lens structures which have characteristic scales of $15-30 \mathrm{~km}$ (described further below). It is important to note that while these scales were calculated as decorrelation length scales, Seaglider 16 was moving in space and time. Moving 
at typically $18 \mathrm{~km}$ a day, it is sampling along lines in the frequency-wavenumber spectrum. Hence the spatial interpretation here applies particularly to regions where properties are changing on slow time scales. Overall, short decorrelation scales show the strong heterogeneity in biological properties within the mixed layer, emphasizing the need for high-resolution measurements like those by Seaglider.

Surface oxygen, an indicator of time-integrated net production modulated by physical mixing, also covaries with fluorescence bloom intensity. Fig. 7 shows Seaglider oxygen for October 2004 through August 2005 averaged in the top $40 \mathrm{~m}$. Wintertime values are lower, and subsaturated by $10 \%$, likely due to deep mixing of surface waters with relatively oxygen depleted deeper water. In the spring bloom, oxygen becomes supersaturated by $5-10 \%$ at the end of April, and again at the later observations of high productivity. The annual cycle compares well with measurements by Körtzinger et al. (2008) on a mooring in the southwest Labrador Sea $\left(56.5^{\circ} \mathrm{N}, 52.6^{\circ} \mathrm{W}\right)$ during the same time range. They found wintertime saturation were about $6 \%$ undersaturated, due to convective mixing with subsaturated deep water, and spring blooms up to $10 \%$ supersaturated. In later sections, we have used oxygen saturation relative to fluorescence to comment on the likely time-history of productivity.

\section{Mesoscale biological and physical features}

\subsection{North bloom 85 mesoscale eddies}

As mentioned above, the north region has the highest eddy-kinetic-energy in the Labrador Sea, and Seaglider observations of high fluorescence appeared to be located within and around several mesoscale eddies which have originated in the West Greenland Current. As the glider was making observations, it was deflected by strong horizontal currents into a curvy path shown in Fig. 9. The glider can typically correct for currents up to $20 \mathrm{cms}^{-1}$, but experienced

currents up to $40 \mathrm{cms}^{-1}$ (Fig. 9). Comparing the track deflections and altimetry, it appears 
as though near $58^{\circ} \mathrm{W}$ and $63^{\circ} \mathrm{N}$, the glider encountered a cyclonic-anticyclonic eddy dipole. Sea surface heights were depressed then elevated (not shown), resulting in alternating surface geostrophic currents along an altimeter track (Fig. 9b, black line and arrows). Coincident with the anticyclone were very fresh mixed-layer salinities (Fig. 9a, Lens 4).

Other fresh lenses were identified by applying a threshold salinity gradient along the glider track, resulting in the identification of 5 fresh lenses (Fig. 9a). Two of them appear sequentially in the glider data, but in this mapped view are clearly the same physical feature (Lenses $2 \mathrm{a}$ and $2 \mathrm{~b}$ ). The 4 distinct fresh lenses have core salinities less than $34.2 \mathrm{psu}$ and temperature less than $2^{\circ} \mathrm{C}$ (Fig. 10b, c). At 400-800 m, these lenses also have warm, salty cores of Irminger Sea Water (Fig. 6a, b), indicating that they originated in the boundary currents. Their hydrography is consistent with Irminger Rings, coherent vortex eddies which may or may not have a fresh surface layer, but do have a warm, salty layer with $\theta \approx$ $3.59-4.75^{\circ} \mathrm{C}$ (Lilly et al., 2003; Rykova, 2006). Along the Seaglider track, the fresh lenses are up to $30 \mathrm{~km}$ wide (Fig. 10), and while we do not know the orientation of the glider through an eddy, this is consistent with typical scales Irminger Rings 15-30 km across (Lilly and Rhines, 2002; Prater, 2002; Rykova, 2006; Hátún et al., 2007). Lens 4 appears to have velocities of $30 \mathrm{cms}^{-1}$, also in agreement with observations of Irminger Rings.

Generally, high fluorescence was confined to the low-salinity layer associated with the eddies (Fig. 6a, d). The low-salinity surface layers result in a shallower mixed layer depth which, for the first time in this record, brings the mixed layer depth above Sverdrup's critical depth, a condition required for a spring bloom (not shown). This demonstrates the primary importance of the buoyant freshwater layer associated with the offshore advection of the boundary currents and eddy flow. In the first three lenses, fluorescence, backscatter and dissolved oxygen are uniform in the mixed layer $\left(\approx 3-4 \mathrm{mg} \mathrm{m}^{-3}\right.$, and oxygen supersaturated), then decay in the $20 \mathrm{~m}$ below (Fig. 12). The fourth lens has supersaturated oxygen in the mixed layer though fluorescence has returned to background values. Oxygen to fluorescence ratios can indicate different stages in the life-cycle of a bloom (Nicholson et al., 2008). As 
a bloom develops, oxygen and fluorescence increase. Once the bloom peaks and decays, fluorescence decreases but oxygen supersaturation remains, until consumed by respiration or reduced by gas exchange and physical mixing. This suggests that Lens 4, an anticyclonic eddy, had recently experienced a phytoplankton bloom. That the glider did not observe high fluorescence in Lens 4 may be due to the decline of the local bloom, as evidenced by the annual cycle of SeaWiFs chlorophyll in Fig. $5 \mathrm{~g}$.

For Lenses 1, 2a and 2b, observed during the local peak bloom while fluorescence was still elevated (Fig. 5g), we separated glider profiles taken within the fresh core of the lenses vs between the fresh cores. Averaging these vertical profiles together, we compared salinity and fluorescence bloom intensity inside eddies to those between (Fig. 11). By construction, the salinity inside the lenses is lower (by about $0.15 \mathrm{psu}$ ), while the fluorescence bloom intensity is higher between fresh lenses (by about $0.5 \mathrm{mg} \mathrm{m}^{-3}$ ). There is quite a bit of overlap between variance in the fluorescence profiles, shown by the shaded areas (1 standard deviation at each depth level). The wide range in fluorescence is partially explained by the bloom decaying even from observations of Lens $2 \mathrm{a}$ to Lens 2b, shown in Fig. 12a, last column. The vertical profile of fluorescence from Lens $2 \mathrm{a}$ is higher than from $2 \mathrm{~b}$ (about 4 days later) by about $0.4 \mathrm{mg} \mathrm{m}^{-3}$.

Discussion. Eddies can have several effects on productivity and measurements of chlorophyll: strong haline stratification of the eddies stabilizes the surface layer, creating shallow (20-50 m) mixed layers; vertical velocities associated with eddies may increase the nutrient supply at the surface, bringing deeper nutrient rich waters into the euphotic zone; or, eddies may simply laterally stir a pre-existing patch of chlorophyll, resulting in high-wavenumbers but no additional production (Klein and Lapeyre, 2009).

From Seaglider observations, we found high fluorescence within and at the edges of eddies. The whole region has shallower mixed layer depths than the water farther from eddies. However, because higher fluorescence was observed at the edges of eddies relative to the center, we expect that there was a dynamical influence of the eddy on the biology, possibly a 
concentration of fluorescing material, or a net input of nutrients to the surface euphotic one enhancing local production.

\subsection{Central Labrador Sea \& thermal warming}

The central Labrador Sea bloom was observed between June 11 to July 12, 2005, along $58^{\circ} \mathrm{W}$ on the Labrador slope. Along this track, from mid May to June, the surface waters gradually warmed from less than $3^{\circ}$ to greater than $5^{\circ} \mathrm{C}$ (Fig. 6b). Comparing the time series of sea surface temperature from AMSR-E through cloud observations (not shown), most of the change in temperature that the glider observed was due to the annual cycle of sea surface temperature, rather than the glider traveling southward through a spatial gradient in temperature. In contrast, the gradual salinification of surface waters (from 34.5 to $34.7 \mathrm{psu}$ ) was most likely due to a spatial gradient in sea surface salinities.

Like the north bloom, the central Labrador Sea bloom was concentrated in the mixed layer (top $40 \mathrm{~m}$ ), with a decay to near background levels within $30 \mathrm{~m}$ below (Fig. 12b). Fluorescence and backscatter values are nearly uniform in the mixed layer $\left(3-4 \mathrm{mg} \mathrm{m}^{-3}\right.$ bloom intensity), consistent with a surface concentrated bloom in an actively mixing layer.

Discussion. Following deep winter mixing (1000-2500 m deep), surface nutrient levels are expected to be high. This contrasts with the north bloom, where wintertime mixed layers are confined to the upper 200-300 m. A primary difference between the north and central Labrador Sea is the source of stratification: warm or fresh. In the central Labrador Sea, thermal warming was key to stratifying the surface layer, while the north bloom was strongly haline-stratified. The balance of haline vs thermal stratification is best shown by comparing buoyancy anomaly in the two regions between the surface and a reference depth. While the central Labrador Sea is both thermally and haline stratified (warm and fresh), the north bloom is stratified in spite of destabilizingly cold surface waters (very cold and very fresh) (Fig. 13). Maps of buoyancy anomaly to $500 \mathrm{~m}$ show that this difference is consistent 
between the north Labrador Sea and the central Labrador Sea-indeed the entire subpolar North Atlantic (Bailey et al., 2005).

\subsubsection{Thin layer in Labrador Current}

In the pycnocline on the Labrador shelf, the glider observed a thin layer $(5 \mathrm{~m})$ of high fluorescence and backscatter (up to 1500 fluorescence counts, or $10 \mathrm{mg} \mathrm{m}^{-3}$ of chlorophyll in bloom intensity). This subsurface fluorescence maximum is not visible in SeaWiFS chlorophyll (Fig. 5), nor does it appear in the time series of glider bloom intensity index, which was calculated in the top $20 \mathrm{~m}$ to compare with SeaWiFs. The glider observed the thin layer in two locations, both on the Labrador shelf: the first excursion onto the shelf was at $56.4^{\circ} \mathrm{N}, 57.8^{\circ} \mathrm{W}$ on June 22,2005 , and the second at $54.8-55.1^{\circ} \mathrm{N}, 54.1-54.6^{\circ} \mathrm{W}$ on July $15-16$, 2005. Both times were after the local surface bloom, which occurs in late May to early June (Fig. 5i).

The thin layer was visible in fluorescence, oxygen and backscatter profiles (Fig. 12c), and can be seen in the swath of fluorescence from the entire section (Fig. 6d, circled in red). From the profiles, it is clear that the thin layer is located within the surface pycnocline. Oxygen is also elevated, but peaks more shallowly than does fluorescence by about $5 \mathrm{~m}$, and still within the pycnocline (Fig. 12c).

The thin layer is at distinct isopycnals in the two excursions onto the shelf. All profiles from the two occupations of the Labrador shelf and showing a thin layer are in Fig. 14 row 3, fluorescence in isopycnal space. The layer varied in vertical position (from 15-30 m) but in the first encounter with the shelf (1500 m along track, Fig. 6) it was at the 1027$1027.5 \mathrm{~kg} \mathrm{~m}^{-3}$ isopycnal, and at the second encounter (1900 km along track), it was at the 1025.5-1026.5 $\mathrm{kg} \mathrm{m}^{-3}$ isopycnal (Fig. 14). The earlier, more northerly observations are at a deeper isopycnal than the later observations, but both thin layers were approximately the same thickness $(5 \mathrm{~m})$. 
Discussion. Thin layers can be formed by several mechanisms, including the shearing of an initially thick layer of plankton or nutrients (Ryan et al., 2008; Birch et al., 2008; Stacey et al., 2007), aggregation at a particular isopycnal (Dekshenieks et al., 2001; Alldredge et al., 2002), or surface depletion of nutrients resulting in plankton aggregating at the intersection of the pycnocline and nutricline. Thin layers were observed on the eastern shelf of Greenland (Waniek et al., 2005). In this case, nutrients were not limiting in the surface layer, and the authors suggested that the thin layer results from a sinking layer of biomass or pressure from grazing zooplankton. Nitrate observations on the central Labrador shelf in late May 1997 found high surface nitrate levels $(5-7 \mu \mathrm{M})$ (Head et al., 2000). On the more southerly Labrador shelf $\left(52^{\circ} \mathrm{N}\right.$ in early June), surface nitrate was below $1 \mu \mathrm{M}$ in the top $10 \mathrm{~m}$ but $5 \mu \mathrm{M}$ at $25 \mathrm{~m}$. If nitrate distributions were similar in 2005, then the Seaglider-observed thin layer could be in the intersection of the pycnocline and nutricline.

If we believe the two excursions onto the shelf were observations of a continguous thin layer feature within the Labrador current, then we must explain its evolution in space-time. Surface intensified shearing of an intially thick layer of plankton would result in the upstream measurements being at a deeper isopycnal than the downstream measurements, as observed in this case. However, progressive shearing of an initially thick patch would result in thinning in time as well. However, both observations of the thin layer were about $5 \mathrm{~m}$. Considering only physical evolution, it is possible that the thin layer had achieved a steady-state balance between shearing and diffusion, resulting in a constant final thickness (Birch et al., 2008).

The shallower peak of oxygen is surprising, and contradicts a simple shearing of a thin layer. Oxygen levels reflect time-integrated net productivity, suggesting that production was higher in the shallower layer. The high fluorescence in the lower layer without accompanying high oxygen could indicate that the thin layer is moving deeper in time. An intense bloom such as this one $\left(10 \mathrm{mg} \mathrm{m}^{-3}\right)$ may shade the layers below enough to prevent production. Once nutrients at a level are depleted, the chlorophyll maximum would descend, still within the pycnocline, but to a region of higher nutrients. A shallow peak in oxygen would remain 
until consumed or mixed away.

\subsubsection{Shelf-break front productivity}

As the glider left the Labrador shelf for the second time, it created a high-resolution swath of hydrography and bio-optics in the shelf-break front, seen in the entire Seaglider section (Fig. 6) and in salinity and fluorescence alone (Fig. 15). At the front, a high fluorescence layer well below the mixed layer, sandwiched between the 34.35-34.45 psu isohalines, is approximately $20 \mathrm{~m}$ thick from 30-50 m deep but varying with the depth of the front. Both fluorescence and backscatter are elevated (Fig. 12), though fluorescence decays more rapidly with depth than does backscatter. Oxygen peaks above fluorescence by a few meters, and decays even more rapidly than does fluorescence.

In contrast to the thin layer within the Labrador Current, the shelf-break front productive layer outcrops several hundred kilometers from the shelf, at the $1000 \mathrm{~m}$ isobath. This outcrop is visible in SeaWiFS ocean color as a narrow along-slope region of elevated chlorophyll, lasting well after the primary Labrador slope and central blooms have passed (Fig. 5f, i). On the northern section, the front is steeper, aligning with the 34 psu outcropping isohaline. On the second shelf-break crossing, isopycnals are less steep.

Discussion. Fronts can be sites of high productivity through upwelling of nutrients and sites of downwelling of biomass, contributing to the biological pump (Flierl and Davis, 1993; Spall and Richards, 2000; Allen et al., 2005). This front is also a clear watermass boundary separating the deep boundary currents and the Labrador shelf current. While Seaglider did not have nutrient data available, historical observations by Head et al. (2000) showed variations in nitrate concentration around the shelf-break front. At $55^{\circ} \mathrm{N}$, they found depleted nutrients near the surface in early June, while on either side, surface nitrate was 2-6 $\mu \mathrm{M}$ higher. This is in contrast with the expectation that the front supplies additional nutrients to the surface, unless productivity is also elevated to a point that nutrients are used up 
very quickly. Here, observations of deep fluorescence along the front isopycnals are suggestive of some downwelling of biomass, while the persistent fluorescence even after the surface bloom has decayed, may suggest additional nutrient sources. Oxygen peaks above fluorescence and backscatter by a few meters, and decays more rapidly, possibly because shallower phytoplankton may be more productive, having access to more light.

\section{Conclusion}

Seaglider 16 crossed the Labrador Sea during the spring and summer of 2005, making coincident high-resolution measurements of salinity, temperature, fluorescence, optical backscatter and oxygen along a sawtooth path. Along the transect, it crossed several distinct biogeographical regimes. The north Labrador Sea bloom is early and intense, and produces the greatest quantity and biomass of zooplankton in the region (Head et al., 2000; FrajkaWilliams and Rhines, 2008), a consequence of the low salinity layer advected from the Greenland boundary current as eddies plus background mean flow. The central Labrador Sea blooms once thermal warming has stratified the surface layer after deep convection.

In the north Labrador Sea where the deep boundary currents traverse the northern edge of the Labrador basin, the glider observed high fluorescence and oxygen saturation within fresh surface lenses associated with Irminger Rings, with mixed layer depths about 40-50 m, shallower than surrounding water. The first effect of these eddies, as part of the mean offshore advection of low salinity water, is to increase surface stratification which allows the early northern bloom. While eddies at this latitude are only $15-30 \mathrm{~km}$ in diameter, high horizontal resolution Seaglider 16 profiles were able to describe their structure and biological influence. High velocities $\left(>30 \mathrm{cms}^{-1}\right.$ ) prevented Seaglider 16 from crossing directly through the eddy, but it was able to distinguish between properties within and between the eddies, showing that fluorescence was elevated at fronts between eddies. This finding, combined with

eddy concentration explaining a fraction of interannual bloom variability (Frajka-Williams 
and Rhines, 2008) suggests that eddies are further responsible for increasing the supply of nutrients in the surface layers of the ocean.

The central Labrador Sea bloom was observed along its western edge on the Labrador slope. This bloom occurred once the region had been thermally stratified, and in 2005 had a higher surface chlorophyll concentration than the north bloom (which is typically the larger bloom). However, Seaglider estimates of depth-integrated chlorophyll are similar between the two regions: $71.4 \pm 37.5 \mathrm{mg} \mathrm{m}^{-2}$ in the north, and $71.1 \pm 22.0 \mathrm{mg} \mathrm{m}^{-2}$ in the central Labrador Sea bloom.

The Seaglider strength was again demonstrated in the observations of two subsurface high fluorescence regions: a thin layer within the equatorward Labrador shelf current and at the Labrador shelfbreak front. In the very fresh, cold Labrador Current, Seaglider 16 found a layer of high fluorescence at the based of a thermally-warmed mixed layer. This thin layer had chlorophyll values of up to $10 \mathrm{mgm}^{-3}$, and while only $5 \mathrm{~m}$ thick, was persistent. Seaglider made two excursions onto the shelf, roughly 1 month apart, finding that the thin layer was present at denser isopycnals upstream (north) and lighter isopycnals downstream (south). This pattern is consistent with a vertical shearing of an initially thicker patch of chlorophyll at the mixed layer base. However, a phasing of oxygen and fluorescence (oxygen peaks shallower than fluorescence) suggests a deepening of the productive region through the pycnocline-and possibly nutricline-as surface nutrients are depleted.

The Labrador shelf-break front was home to a second subsurface layer of high fluorescence, backscatter and oxygen. This layer was sandwiched within the isopycnals defining the front, and outcropped at the $1000 \mathrm{~m}$ isobath where it was visible from SeaWiFS ocean color. The deep occurrence of high fluorescence is suggestive of a downwelling of biomass, while the persistence of fluorescence after the surface bloom had decayed may suggest an upwelling of nutrients.

While our understanding of the linkage between physical processes and biological productivity was limited by the absence of nutrient data, high resolution data in horizontal 
and vertical space from the Seaglider 16 allowed an unprecedented view of in situ physicalbiological connections in the Labrador Sea. Calculations of decorrelation length scales showed that biological variables in particular decorrelated on scales of $20-30 \mathrm{~km}$, emphasizing the need for high resolution observations. This study complements the larger-scale, longer term observations by satellite (Wu et al., 2008; Frajka-Williams and Rhines, 2008) by illuminating mesoscale physical and biological features which may be responsible for large-scale bloom patterns.

\section{Acknowledgements}

This work was performed with support from NSF Physical Oceanography grant. Eleanor Frajka Williams was supported by an NSF graduate research fellowship for a part of this work. The manuscript was much improved due to comments from anonymous reviewers. Helpful discussions were had with Eric D'Asaro, Steve Emerson, Bruce Frost, Amanda Gray, Jonathan Lilly, David Nicholson, Eric Rehm and Brandon Sackmann. Many thanks to the people who gathered or provided data used here including the Seaglider teams, Igor Yashayaev, SeaWiFS data people, Mathieu Ouellet, and DFO BioChem database.

\section{References}

Alldredge, A. L., Cowles, T. J., MacIntyre, S., Rines, J. E. B., Donaghay, P. L., Greenlaw, C. F., Holliday, D. V., Dekshenieks, M. M., Sullivan, J. M., and Zaneveld, J. R. V. (2002). Occurrence and mechanisms of formation of a dramatic thin layer of marine snow in a shallow Pacific fjord. Marine Ecology Progress Series, 233:1-12.

Allen, J. T., Brown, L., Sanders, R., Moore, C. M., Mustard, A., Fielding, S., Lucas, M., Rixen, M., Savidge, G., Henson, S., and Mayor, D. (2005). Diatom carbon export enhanced by silicate upwelling in the northeast Atlantic. Letters to Nature, 437:728-732. 
Bailey, D. A., Rhines, P. B., and Hakkinen, S. (2005). Formation and pathways of North Atlantic Deep Water in a coupled ice-ocean model of the Arctic-North Atlantic Oceans. Journal of Climate, 25:497-516.

Behrenfeld, M. J. and Boss, E. (2003). The beam attenuation to chlorophyll ratio: an optical index of phytoplankton physiology in the surface ocean? Deep Sea Research, 50:1537-1549.

Birch, D. A., Young, W. R., and Franks, P. J. S. (2008). Thin layers of plankton: Formation by shear and death by diffusion. Deep Sea Research, 55:277-295.

Boss, E., Swift, D., Taylor, L., Brickley, P., Zaneveld, J. R. V., Riser, S., and Perry, M. J. (2008). Robotic in-situ and satellite based observations of pigment and particle distributions in the western North Atlantic. Limnology and Oceanography.

Cota, G. F., Harrison, W. G., Platt, T., Sathyendranath, S., and Stuart, V. (2003). Biooptical properties of the Labrador Sea. Journal of Geophysical Research, 108(C7).

Dekshenieks, M. M., Donaghay, P. L., Sullivan, J. M., Rines, J. E. B., Osborn, T. R., and Twardowski, M. S. (2001). Temporal and spatial occurrence of thin phytoplankton layers in relation to physical processes. Marine Ecology Progress Series, 223:61-71.

Eriksen, C. C., Osse, T. J., Light, R. D., Wen, T., Lehman, T. W., Sabin, P. L., Ballard, J. W., and Chiodi, A. M. (2001). Seaglider: a long-range autonomous underwater vehicle for oceanographic research. IEEE Journal of Oceanic Engineering, 26:424-436.

Eriksen, C. C. and Rhines, P. (2008). Convective- to gyrescale-dynamics, the first seaglider campaigns, 2003-2005. In Dickson, R. R., Meincke, J., and Rhines, P., editors, ArcticSubarctic Ocean Fluxes: Defining the Role of the Northern Seas in Climate, pages 613-628. Springer.

Feldman, G. C. and McClain, C. R. (2006). Ocean color web: SeaWIFs. In Kuring, N. and Bailey, S. W., editors, NASA Goddard Space Flight Center. 
Fennel, K. and Boss, E. (2003). Subsurface maxima of phytoplankton and chlorophyll: Steady-state solutions from a simple model. Limnology and Oceanography, 48:1521-1534.

Flierl, G. R. and Davis, C. S. (1993). Biological effects of Gulf Stream meandering. Journal of Marine Research, 51:529-560.

Frajka-Williams, E. and Rhines, P. (2008). Offshore advection of freshwater and the Labrador Sea spring bloom from SeaWiFS, in prep. Deep Sea Research.

Hátún, H., Eriksen, C. C., and Rhines, P. B. (2007). Buoyant eddies entering the Labrador Sea observed with gliders and altimetry. Journal of Physical Oceanography, 37:2838-2854.

Head, E. J. H., Harris, L. R., and Campbell, R. W. (2000). Investigations on the ecology of Calanus spp. in the Labrador Sea. I. relationship between the phytoplankton bloom and reproduction and development of Calanus finmarchicus in spring. Marine Ecology Progress Series, 193:53-73.

Klein, P. and Lapeyre, G. (2009). The oceanic vertical pump induced by mesoscale and submesoscale turbulence. Annual Reviews of Marine Science, 1:351-375.

Körtzinger, A., Send, U., Wallace, D. W. R., Karstensen, J., and DeGrandpre, M. (2008). Seasonal cycle of $\mathrm{O}_{2}$ and $p \mathrm{CO}_{2}$ in the central Labrador Sea: Atmospheric, biological and physical implications. Global Biogeochemical Cycles, 22(GB1014).

Lilly, J. M. and Rhines, P. B. (2002). Coherent eddies in the Labrador Sea observed from a mooring. Journal of Physical Oceanography, 32:585-598.

Lilly, J. M., Rhines, P. B., Schott, F., Lavender, K., Lazier, J., Send, U., and D'Asaro, E. (2003). Observations of the Labrador Sea eddy field. Progress in Oceanography, 59:75-176.

Lueck, R. G. (1990). Thermal inertia of conductivity cells: Theory. Journal of Atmospheric and Oceanic Technology, 7:741-755. 
Lutz, V. A., Sathyendranath, S., Head, E. J. H., and Li, W. K. W. (2003). Variability in pigment composition and optical characteristics of phytoplankton in the Labrador Sea and the central North Atlantic. Marine Ecology Progress Series, 260:1-18.

Nicholson, D., Emerson, S., and Eriksen, C. C. (2008). Net community production in the deep euphotic zone of the subtropical North Pacific gyre from glider surveys. Limnology and Oceanography, 53:2226-2236.

Perry, M. J., Sackmann, B. S., Eriksen, C. C., and Lee, C. M. (2008). Seaglider observations of blooms and subsurface chlorophyll maxima off the Washington coast. Limnology and Oceanography, pages 2169-2179.

Prater, M. D. (2002). Eddies in the Labrador Sea as observed by profiling RAFOS floats and remote sensing. Journal of Physical Oceanography, 32:411-427.

Ryan, J. P., McManus, M. A., Paduan, J. D., and Chavez, F. P. (2008). Phytoplankton thin layers caused by shear in frontal zones of a coastal upwelling system. Marine Ecology Progress Series, 354:21-34.

Rykova, T. (2006). Evolution of the Irminger Current Anticyclones in the Labrador Sea from hydrographic data. Master's thesis, Massachusetts Institute of Technology and Woods Hole Oceanographic Institution, Woods Hole, MA.

Sackmann, B. S. (2007). Remote Assessment of 4-D phytoplankton distributions off the Washington Coast. Doctor of philosophy, University of Maine, Orono, Maine.

Sackmann, B. S., Perry, M. J., and Eriksen, C. C. (2008). Seaglider observations of variability in daytime fluorescence quenching of chlorophyll-a in Northeastern Pacific coastal waters submitted. Biogeosciences.

Spall, S. A. and Richards, K. J. (2000). A numerical model of mesoscale frontal instabilities and plankton dynamics - I. Model formulation and initial experiments. Deep Sea Research, 47:1261-1301. 
Stacey, M. T., McManus, M. A., and Steinbuck, J. V. (2007). Convergences and divergences and thin layer formation and maintenance. Limnology and Oceanography, 52:1523-1532.

Waniek, J. J., Holliday, N. P., Davidson, R., Brown, L., and Henson, S. A. (2005). Freshwater control of onset and species composition of Greenland shelf spring bloom. Marine Ecology Progress Series, 288:45-57.

Wu, Y., Platt, T., Tang, C. C. L., and Sathyendranath, S. (2008). Regional differences in the timing of the spring bloom in the Labrador Sea. Marine Ecology Progress Series, 355:9-20. 


\section{Figures}

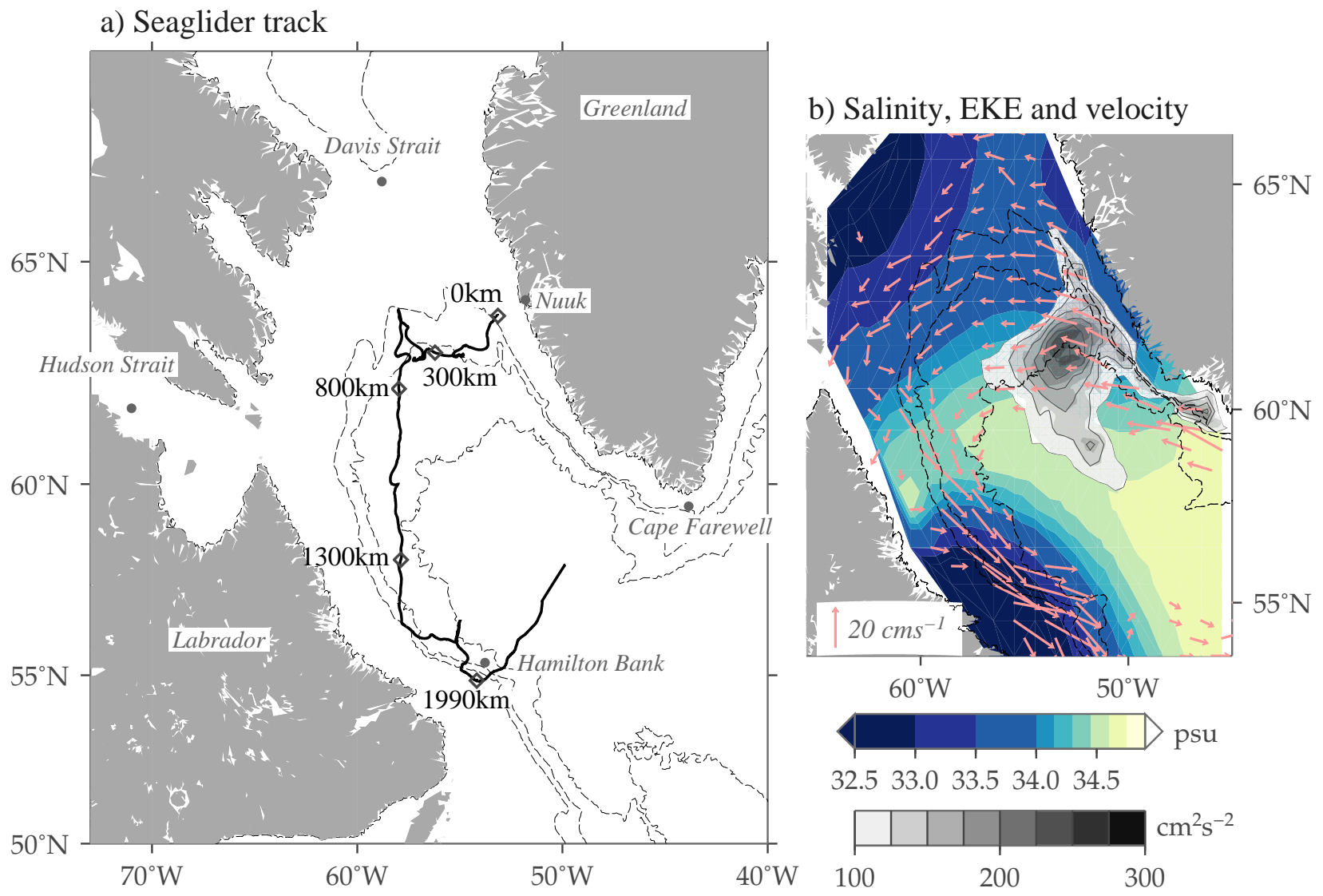

Figure 1: The Labrador Sea is situated between Labrador in Canada and Greenland. (a) The glider track in the Labrador Sea and (b) climatological sea surface salinity, eddy-kineticenergy and mean surface currents. Landmasses, locations and bathymetric contours at $1000 \mathrm{~m}$ intervals are marked. Distance along the glider track is marked in kilometers, indicated by diamonds along the track. Sea surface salinity is from the World Ocean Atlas 2005, March (blue colormap); Eddy-kinetic-energy is from the Aviso velocity anomaly product (1992-2007, grayscale colormap) and mean currents from the Aviso mean velocity product (1992-2007, pink arrows). 
a) Glider and AR7w oxygen

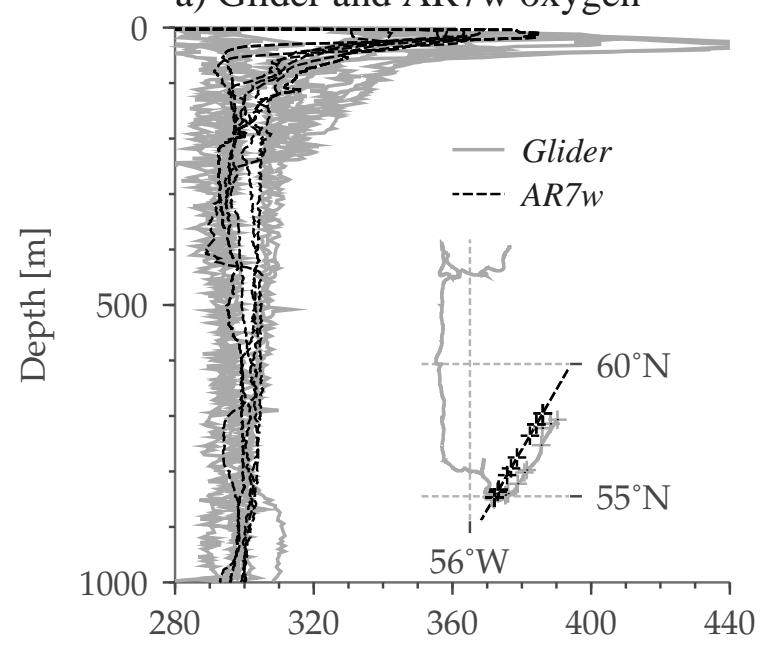

b) Scatter of oxygen

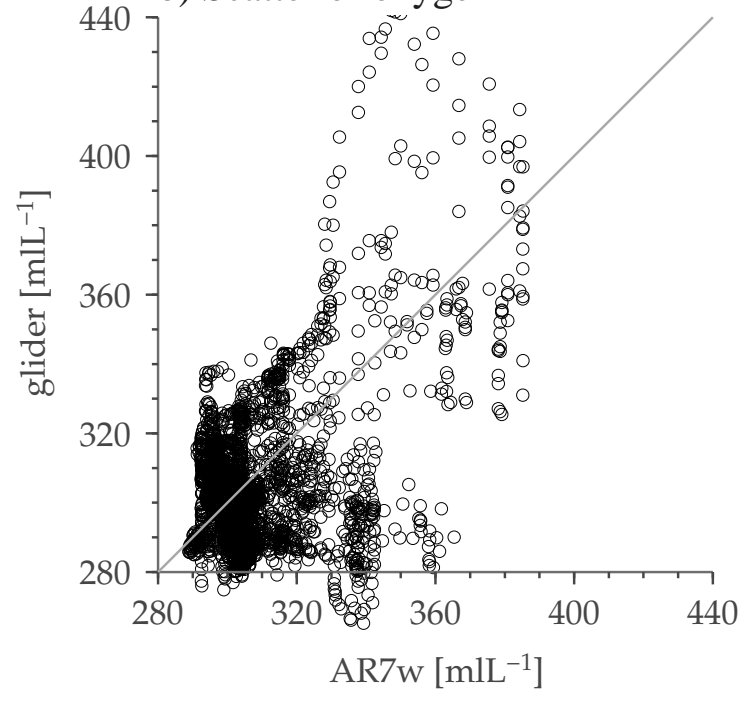

Figure 2: Seaglider oxygen electrode measurements are calibrated against measurements taken during the AR7w repeat hydrography section. (a) Calibrated Seaglider (gray, solid) and ship cruise measurement profiles (black, dashed) are paired based on minimal distance in time and space (within $50 \mathrm{~km}$ and 2 weeks). Profile locations are shown at crosses on the inset map-black is the AR7w cruise, gray is the glider track. (b) Scatter plot of glider oxygen against AR7w oxygen. Each point represents a pair of measurements from a cruise profile and glider profile, from the same depth. The largest divergences between Seaglider and ship measurements are in the surface layers. 

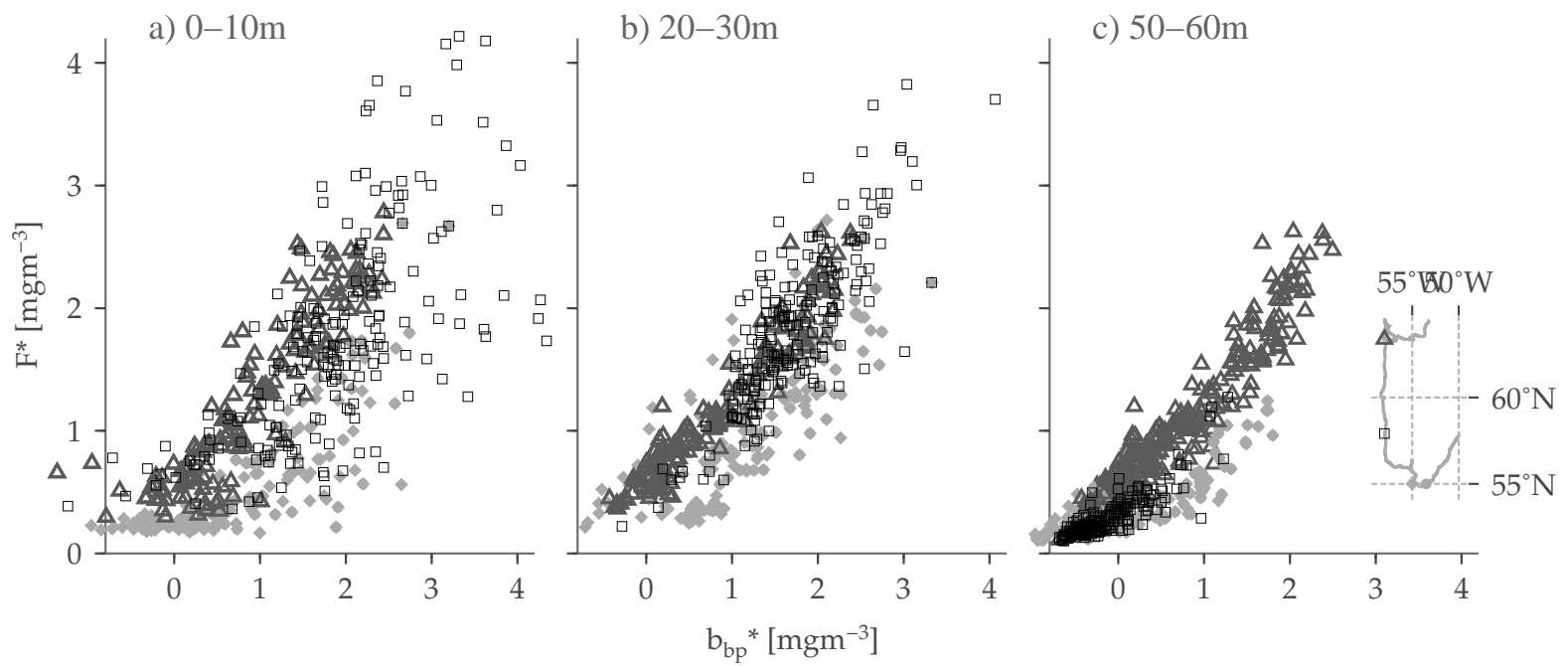

Figure 3: Scatterplots of fluorescence bloom intensity $\left(\mathrm{F}^{*}\right)$ vs $\mathrm{b}_{b p}$ bloom intensity $\left(\mathrm{b}_{b p}{ }^{*}\right)$ for profiles from 4 productive regions, the north slope, central Labrador Sea, Labrador shelf thin layer and shelf-break front (indicated by symbols along the track in the inset map). The first two regions (black triangle and black square) are mixed layer blooms while the second two are subsurface (gray diamond and circle). Observations were binned by depth, (a) 0$10 \mathrm{~m}$, (b) 20-30 m, (c) 50-60 m. At the surface (a), $\mathrm{F}^{*}$ and $\mathrm{b}_{b p} *$ are high, with large spread (loose correlation) especially in the Labrador slope region ( $\square$ ). In deeper depth bins, the relationship between $\mathrm{F}^{*}$ and $\mathrm{b}_{b p}{ }^{*}$ is tighter. By $50-60 \mathrm{~m}$ (c), only the north bloom region $(\triangle)$ has high values. 

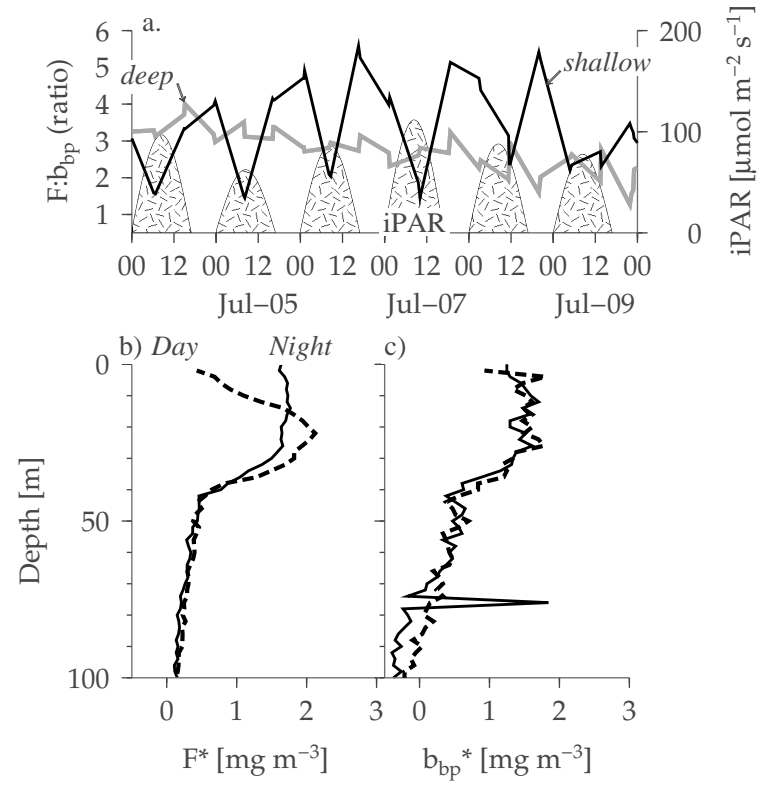

Figure 4: a) Near-surface (0-10 m, black line) and deeper (20-30 m, gray line) values of $\mathrm{F}: \mathrm{b}_{b p}$ (fluorescence to backscatter ratio), and SeaWiFS iPAR (instantaneous incident light, hatched regions, described in §2) for July 4-9, 2005. Lower surface F: $b_{b p}$ ratios are observed during the daytime (higher iPAR), indicative of fluorescence quenching. (b) Daytime and nighttime vertical profiles of $\mathrm{F}^{*}$ and $\mathrm{b}_{b p}$ show the depth range over which fluorescence is quenched $(0-30 \mathrm{~m})$, while $\mathrm{b}_{b p}$ is relatively constant in the surface layer. 
a) Apr 21-May 18

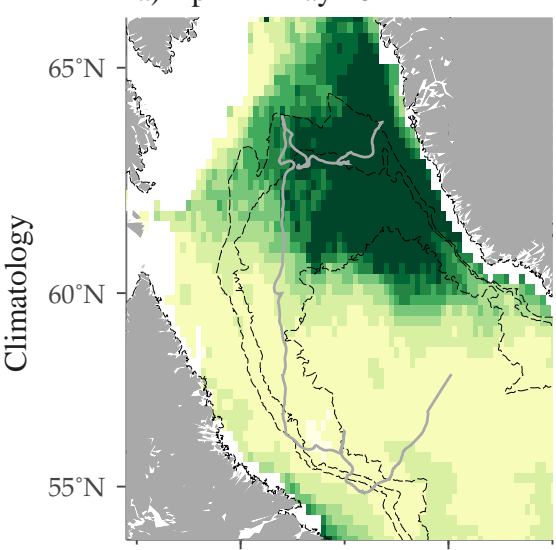

d) 2005: Apr 21-May 18
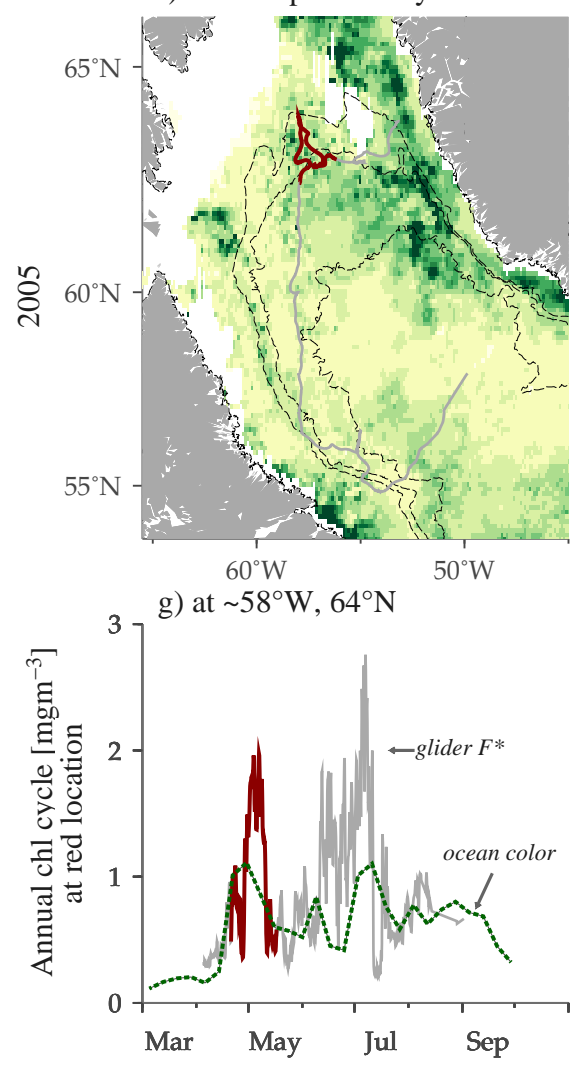

b) Jun 11-Jul 12

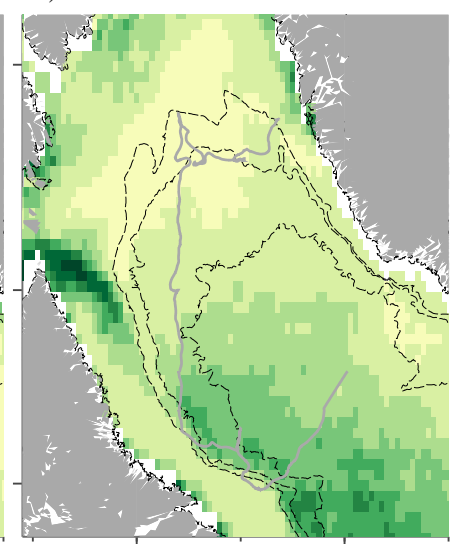

e) 2005: Jun 11-Jul 12

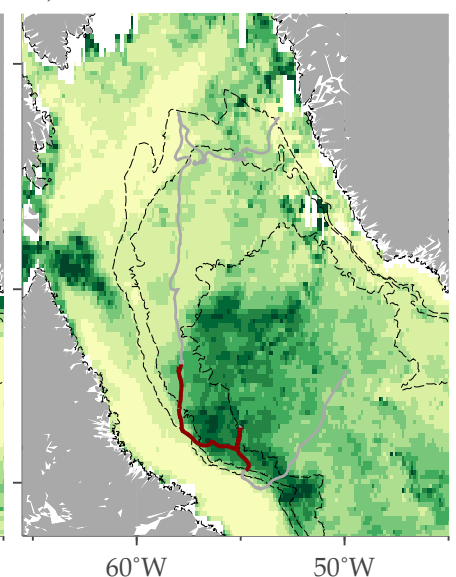

h) at $\sim 57^{\circ} \mathrm{W}, 57^{\circ} \mathrm{N}$ c) Jul 12-Aug 1

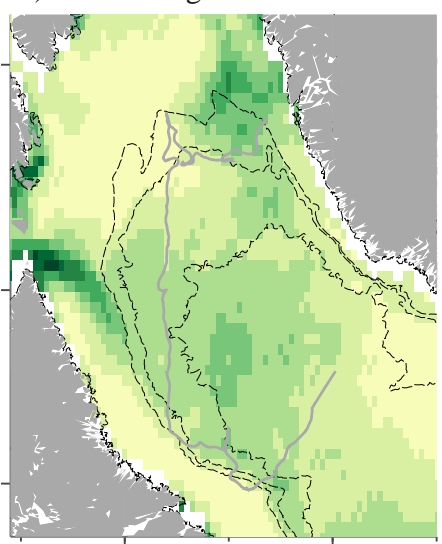

f) 2005: Jul 12-Aug 1

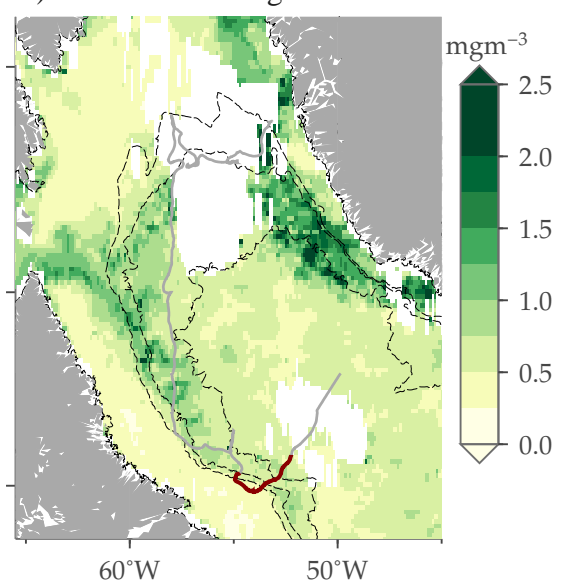

i) at $\sim 54^{\circ} \mathrm{W}, 55^{\circ} \mathrm{N}$

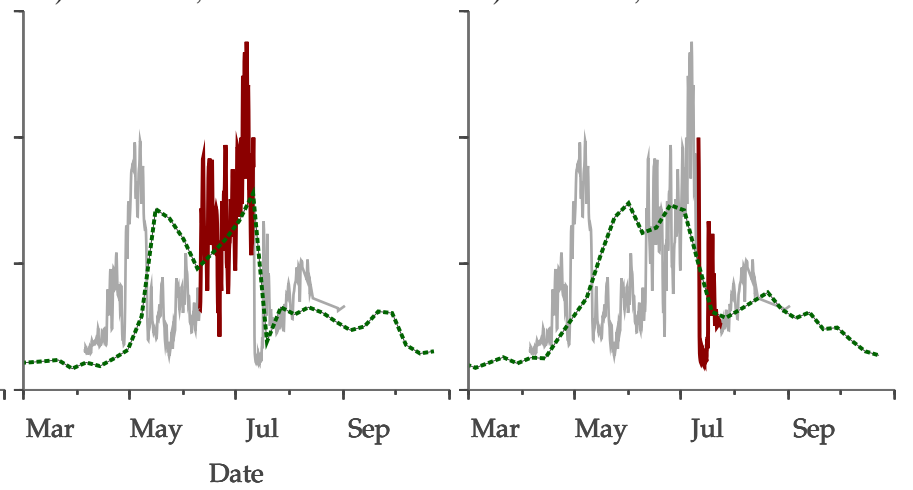

Figure 5: Comparison of climatological and 2005 surface chlorophyll (rows 1: a-c and 2: d-f, with glider track marked in gray), and glider chlorophyll measurements in the top $20 \mathrm{~m}$ with SeaWiFS chlorophyll annual cycle (row 3: g-i). The three time periods for each column are roughly one month long and correspond to the glider location highlighted in red in row 2. In this way, we can see the spatial pattern of chlorophyll while the glider made a single track of measurements. For the annual cycles in row 3, SeaWiFS chlorophyll (green) is from the location in row 2, allowing a direct comparison between Seaglider measurements and SeaWiFS where the Seaglider chlorophyll is highlighted in red. Row 3 shows when the Seaglider measured chlorophyll relative to the local bloom timing. From (g) we see that the glider observations during this region and time were during the local peak and decline of the bloom. From (h) we see that glider observed a secondary peak for this region. From (i) we see that the glider made observations after the local peak bloom had declined. 


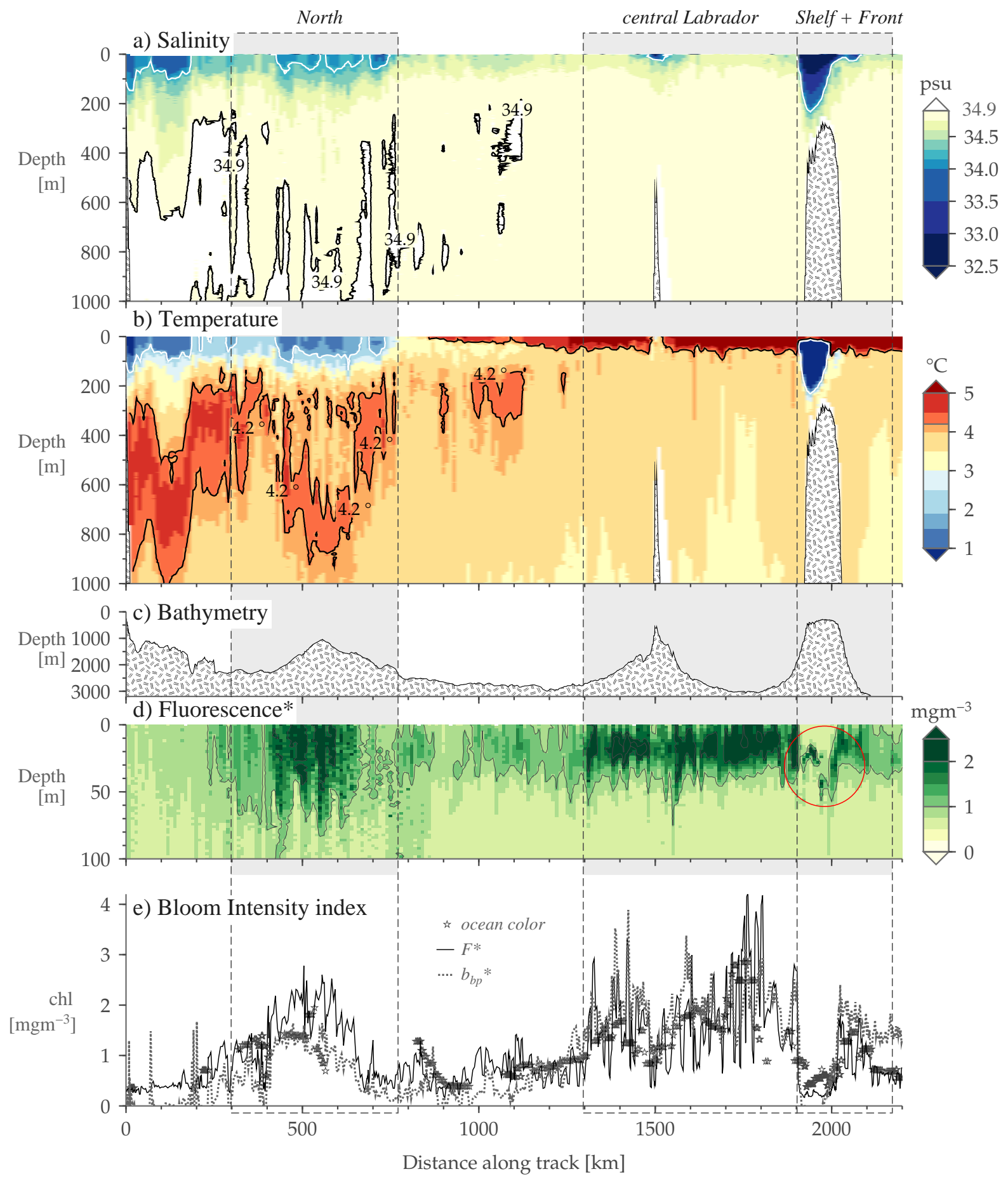

Figure 6: The entire section of Seaglider salinity (a) and potential temperature (b) to $1000 \mathrm{~m}$, underlying bathymetry along the track (c), fluorescence bloom intensity to $100 \mathrm{~m}$ (d) and bloom intensity indices (e). High fluorescence regions along the track are highlighted in gray: the north bloom $(300-800 \mathrm{~km})$, the central Labrador $(1300-1900 \mathrm{~km})$ and the Labrador shelf and front (1900-2000 km). The north bloom region has a watermass signature similar to West Greenland Current observations (fresh surface, and subsurface core of warm, salty Irminger Sea Water). The central Labrador region has a warm surface layer. The Labrador shelf is very cold and fresh. (d) The thin layer on the Labrador shelf is circled in red on the fluorescence panel. (e) Ocean color within 2 days and 0.5 degrees of the glider surfacing locations are included on the plot of $\mathrm{F}^{*}$ and $\mathrm{b}_{b p}{ }^{*}$. 


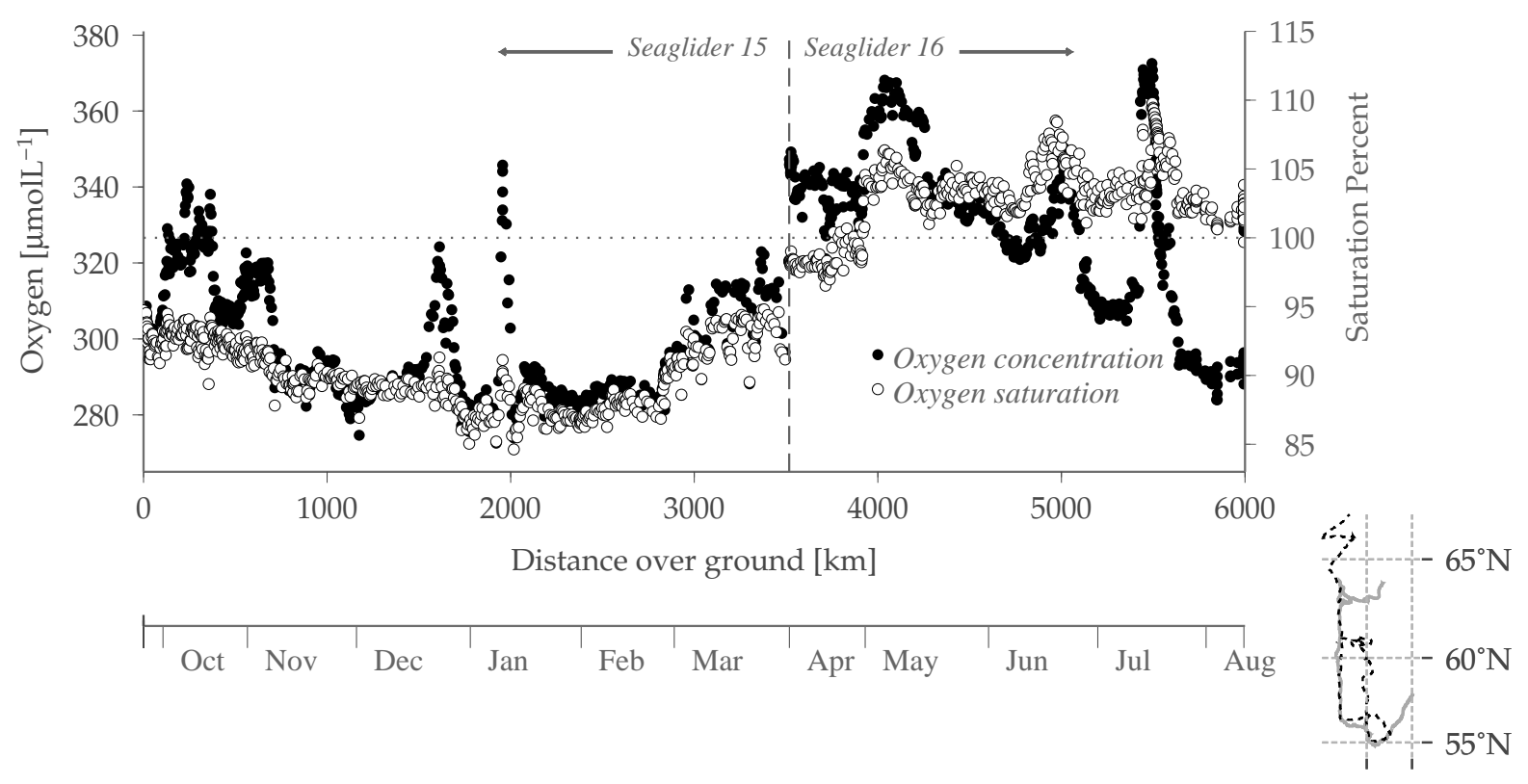

Figure 7: Surface (0-40 m) time/space series of oxygen concentration and saturation measured by Seaglider 15 (October 2004-March 2005, dashed track in inset map) and Seaglider 16 (April - August 2005, solid track in inset map). In the wintertime in the Labrador Sea, productivity is absent or very low, due to low light levels. During deep convection (January through March) surface waters are mixed with oxygen depleted waters below, decreasing saturation to $10 \%$ subsaturated. In the spring bloom, oxygen levels soar, becoming supersaturated by $5-10 \%$ at the end of April, and remaining supersaturated through the end of the record (mid-August). Though supersaturated everywhere in the springtime, oxygen concentrations decrease from April to August due to warming. 
a) Mixed layer properties

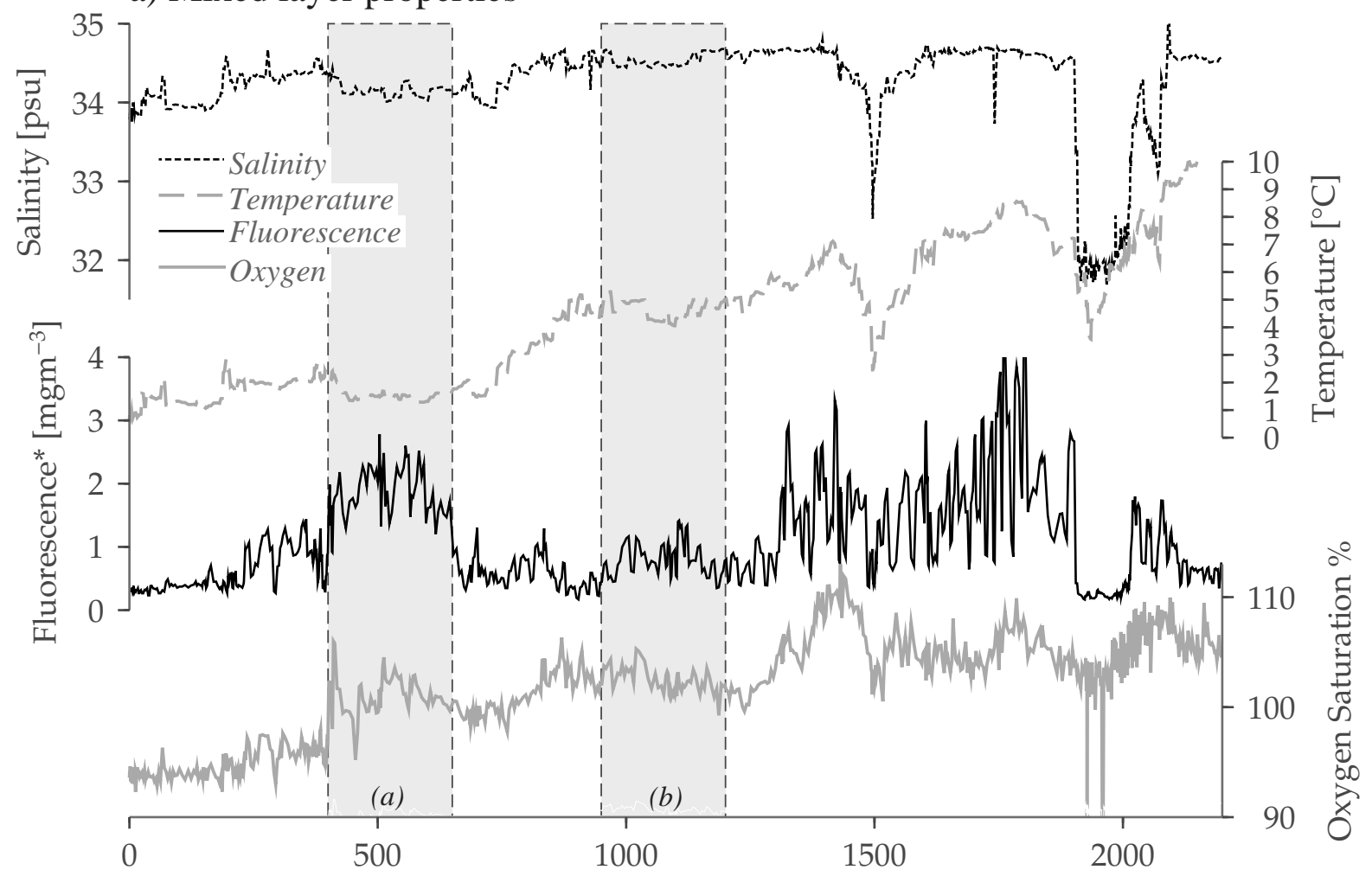

Distance along track $[\mathrm{km}]$
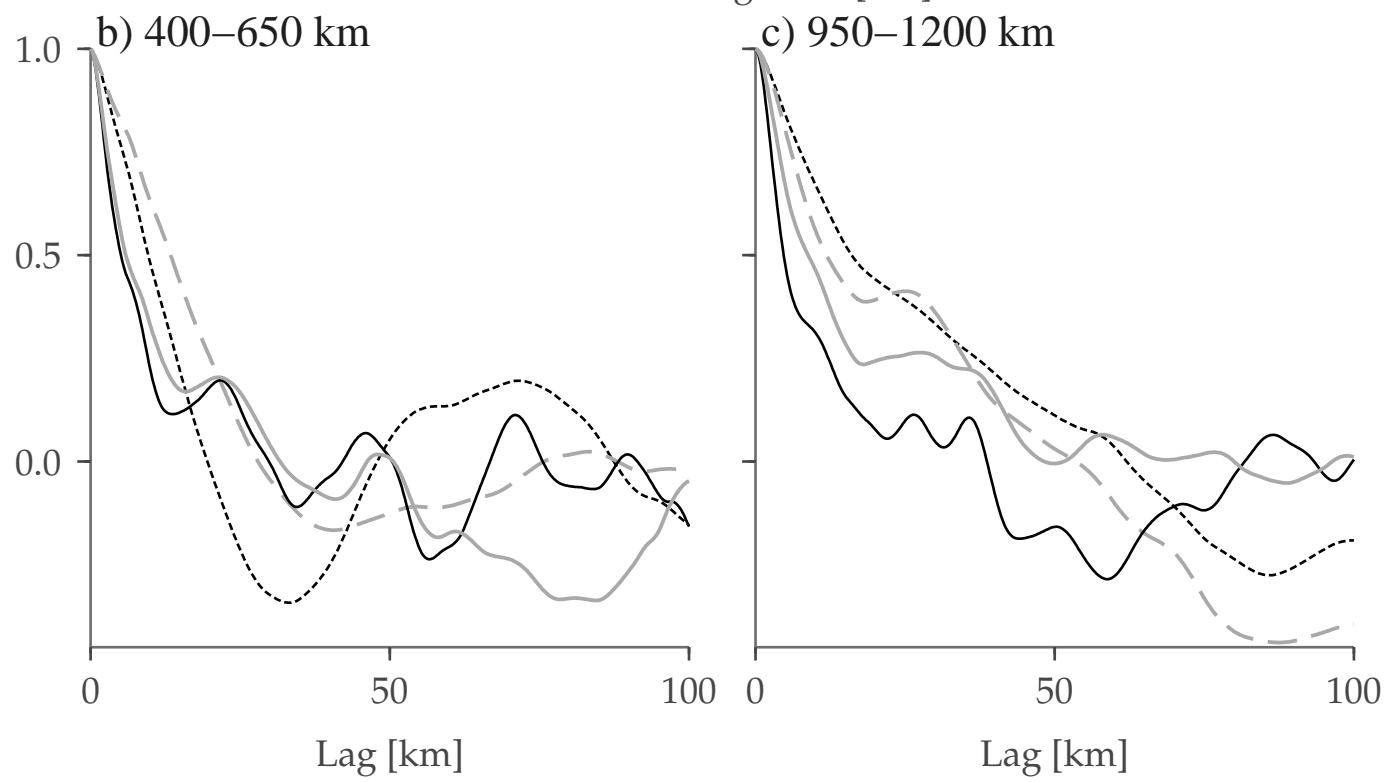

Figure 8: Auto-correlations between mixed layer properties. Panel (a) shows the mixed layer salinity, temperature, fluorescence and oxygen saturation for the entire Seaglider 16 record. Panels (b) and (c) are lag correlations as a function of distance along track for each variable, within two regions (shaded in panel (a)), the north Labrador bloom and part of the early central Labrador bloom. In the north bloom, where mesoscale eddies of diameter $\approx 20 \mathrm{~km}$ were present, all properties decorrelated more quickly. In the central Labrador Sea, biological properties decorrelated much more rapidly than did salinity or temperature. Temperature in particular was affected by seasonal warming so that later in the season, decorrelation length scales increase to $100 \mathrm{~km}$ (not shown). 


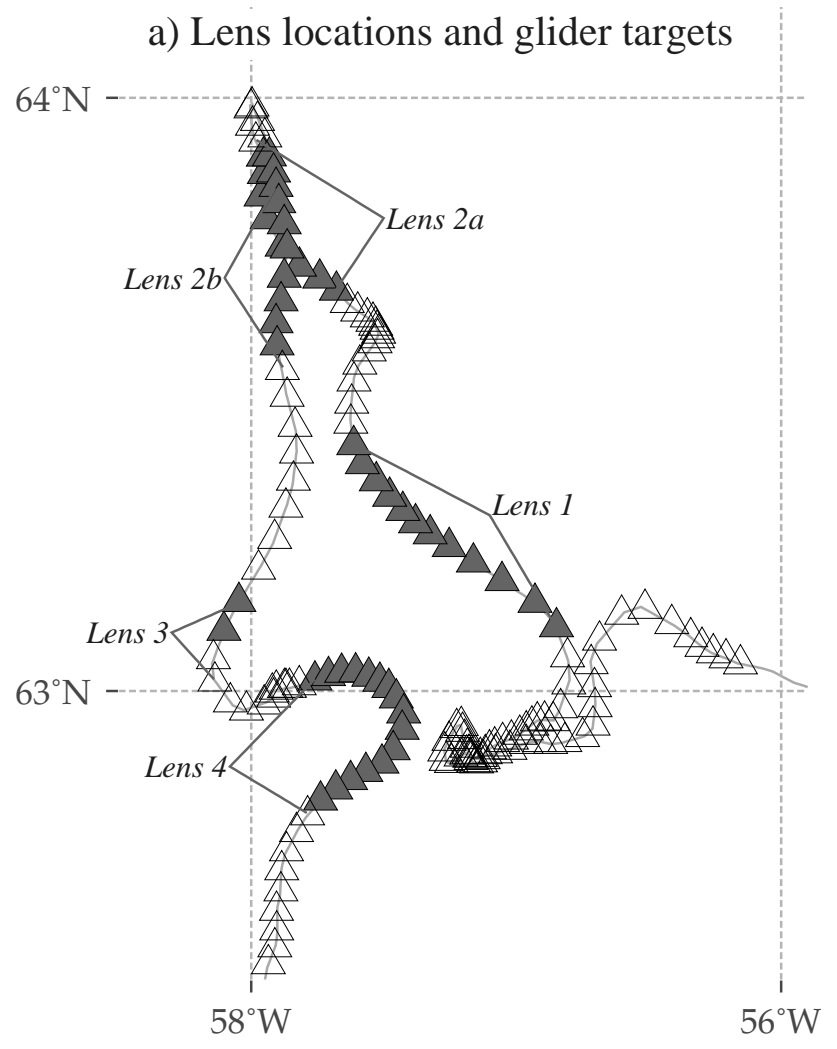

\section{b) Currents}

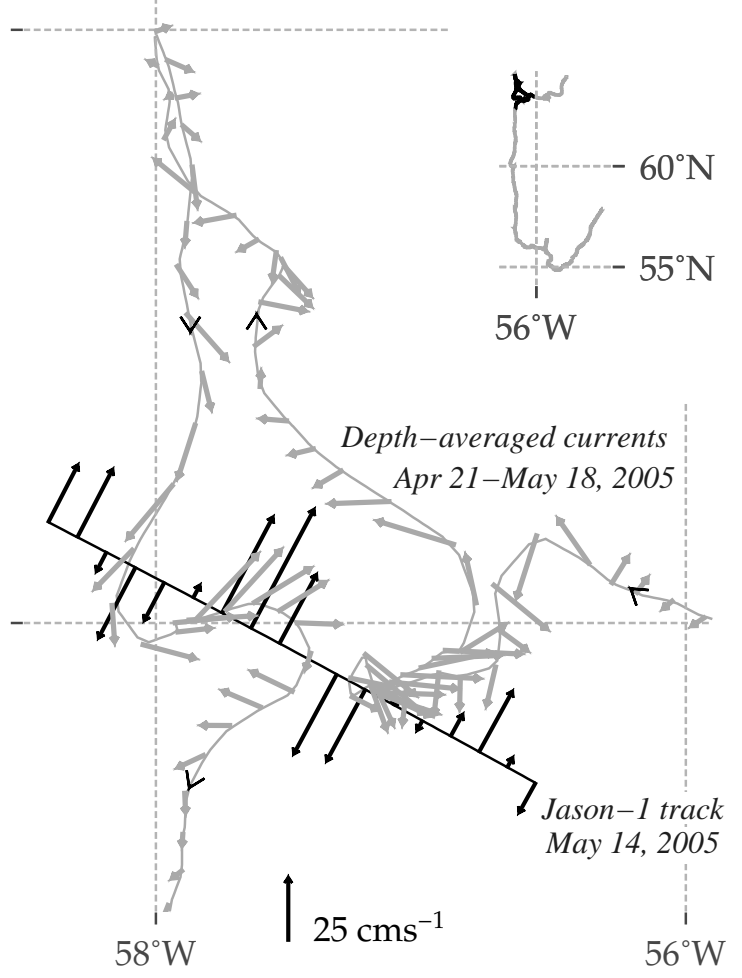

Figure 9: Spatial map of glider observations of 4 fresh lenses and surface velocities. (a) Each profile is marked by a circle. Gray profiles are within fresh lenses, open circles are outside or between lenses. From this map it is clear that lens $2 \mathrm{a}$ and $2 \mathrm{~b}$ are the same physical feature. (b) Glider-estimated 0-1000 m depth-averaged currents (gray arrows) and surface geostrophic velocities from an along-track-gridded altimetry section (black arrows) show the anticyclonic, vortex structure of lens 4. Glider direction of travel is shown by the small black arrowheads along the track. Along this survey, the glider was deflected from straight lines in the westward, northwestward then due south directions by ocean currents. 


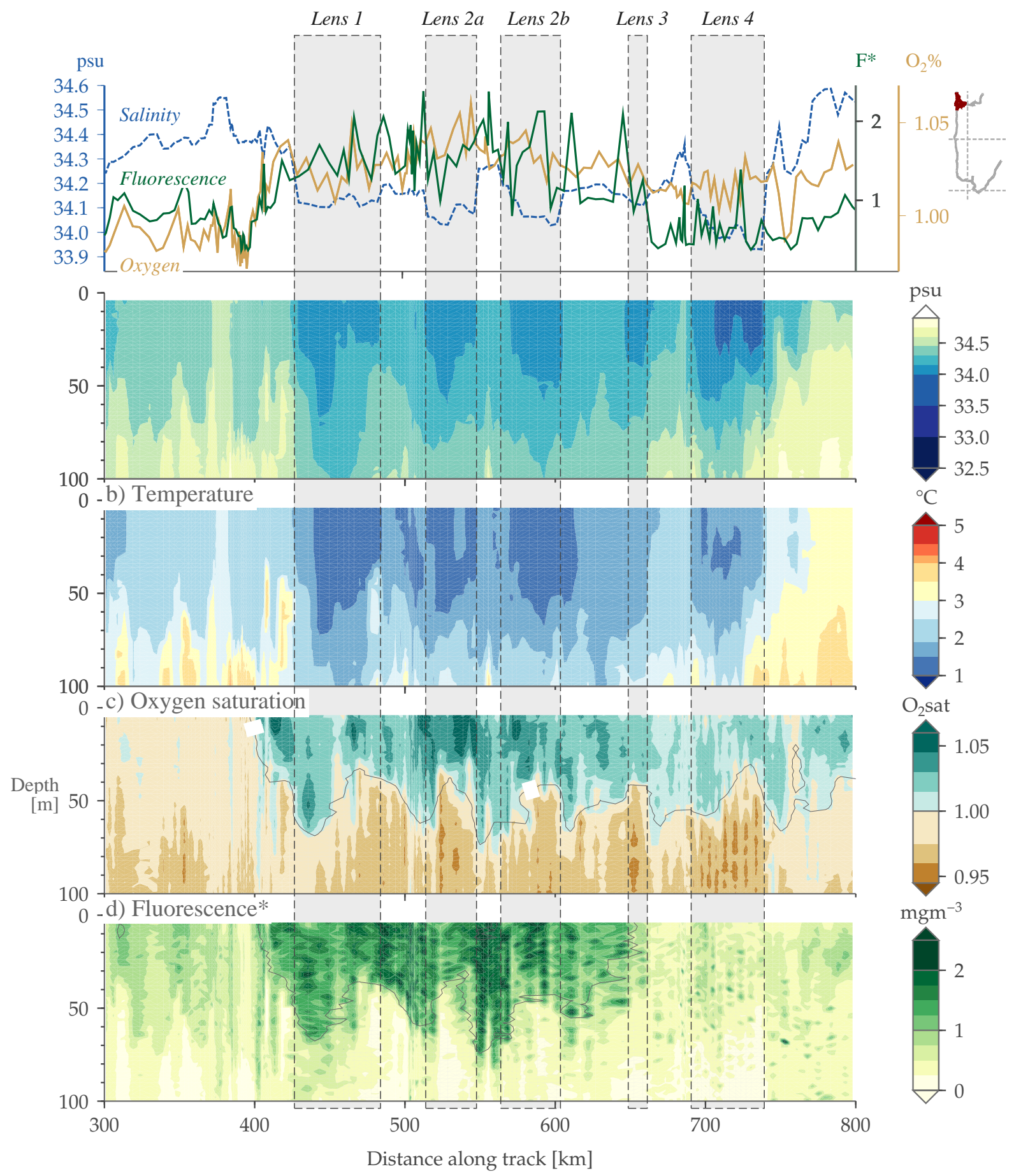

Figure 10: Hydrography and biological data from Seaglider in the north bloom: salinity (b), potential temperature (c), oxygen saturation (d), and fluorescence bloom intensity, $\mathrm{F}^{*}(\mathrm{e})$. Highlighted in gray are five observations of four fresh and cold lenses. Higher $\mathrm{F}^{*}$ and oxygen saturation values are seen in lenses 1 and 2. Additionally, oxygen is elevated in lenses 3 and 4. (a) While $\mathrm{F}^{*}$ is higher in the lens region than the $100 \mathrm{~km}$ at the beginning of this plot, some of the highest $\mathrm{F}^{*}$ values are observed between lenses 1 and $2 \mathrm{a}$, and between lenses $2 \mathrm{a}$ and $2 \mathrm{~b}$. 


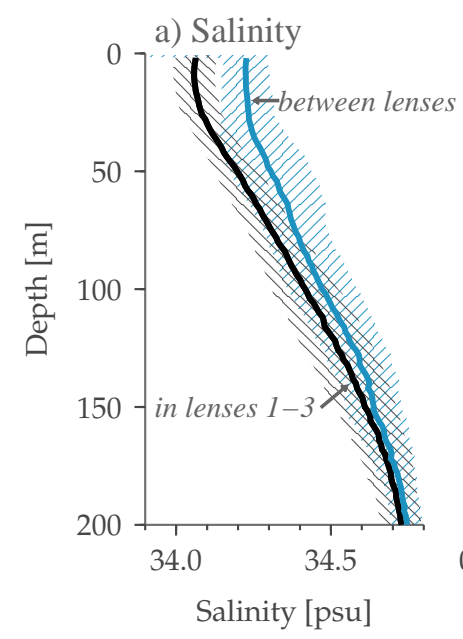

b) Fluorescence*

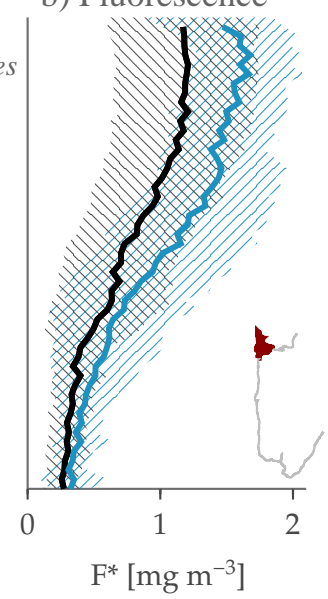

Figure 11: Mean vertical profiles of (a) salinity and (b) fluorescence bloom intensity inside (black) and between (blue-gray) lenses 1-3 in the north region. Lower salinities are in the lenses by definition, while higher average $\mathrm{F}^{*}$ values are between the lenses. Shaded regions around the profiles indicate one standard deviation. 

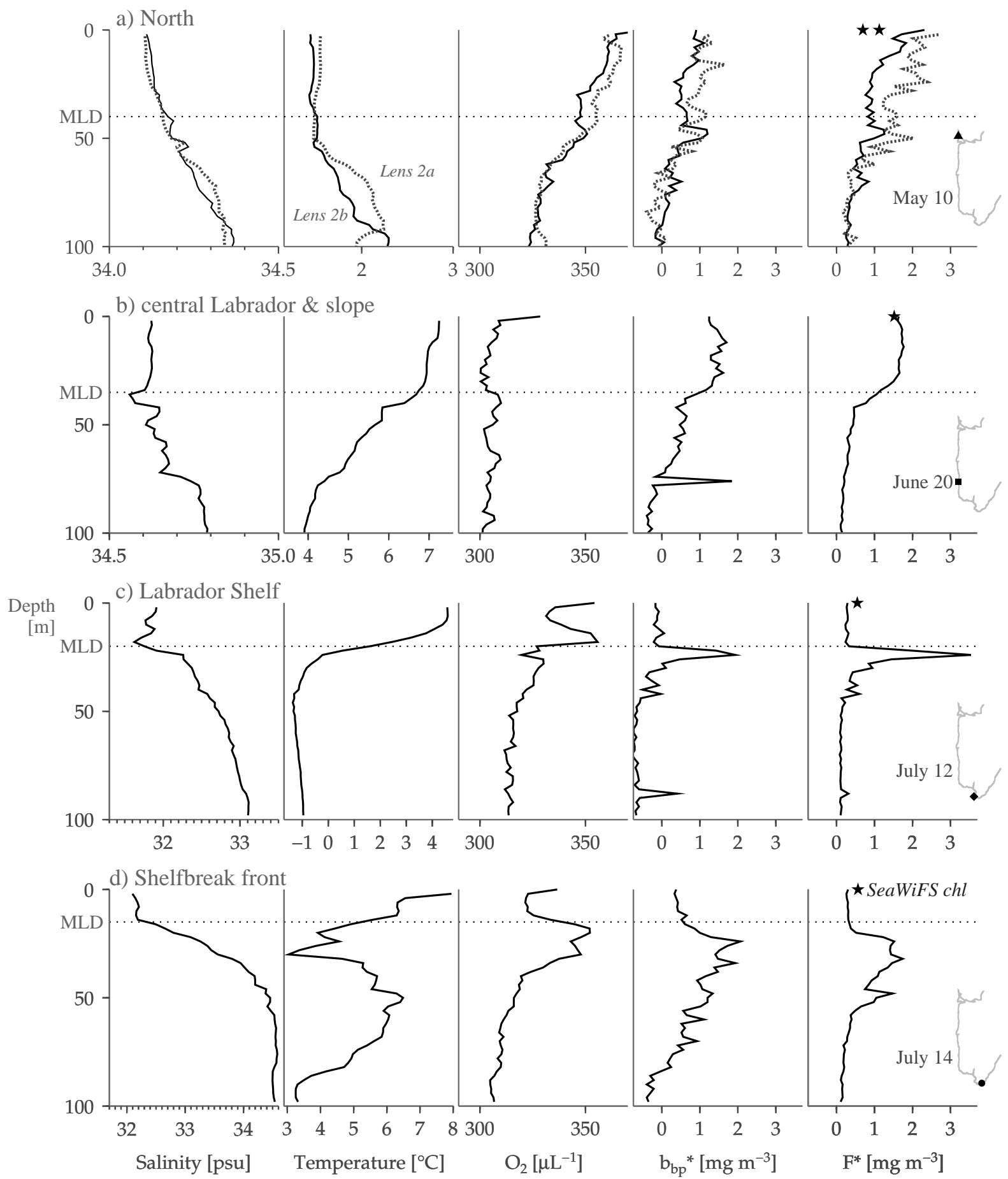

Figure 12: Vertical profiles of salinity (column 1), potential temperature (column 2), dissolved oxygen (column 3), backscatter-derived bloom intensity (column 4) and fluorescence-derived bloom intensity (column 5) for the four productive regions: north slope (row 1), Labrador slope (row 2), Labrador shelf and thin layer (row 3) and shelf-break front (row 4). Mixed layer depth is indicated by the dotted line. Inset plots show the glider track, profile position and the date the profile was taken. For the north slope, profiles are in lens $2 a$ (dotted) and $2 \mathrm{~b}$ (solid), to show the similarity of properties there. SeaWiFS chlorophyll estimates at the time and location nearest the glider profile are shown at the surface in the fluorescence plot (column 5) as black stars. 
Thermal stratification

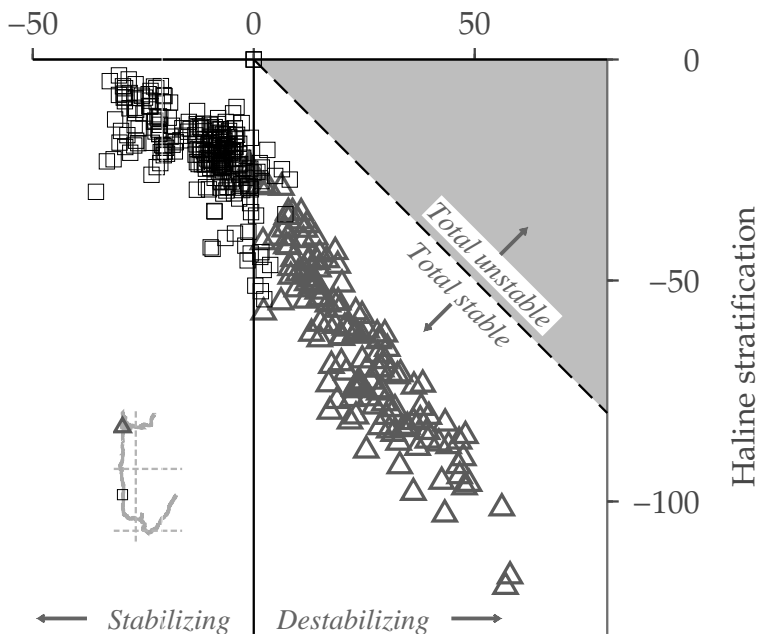

Figure 13: Buoyancy anomaly to $250 \mathrm{~m}$ due to salinity and temperature shows the relative contributions of haline and thermal stratification. Negative buoyancy anomaly is stabilizing, positive is destabilizing. Total buoyancy anomaly is indicated by the distance of a point from the dashed line labeled "Total unstable/total stable". Triangles are for the north bloom region while squares are the central Labrador. In the north region, salinity is stabilizing in spite of very cold, destabilizing temperatures. In the central Labrador, both temperature and salinity are stabilizing.

a) Shelf encounter A b) Shelf encounter B

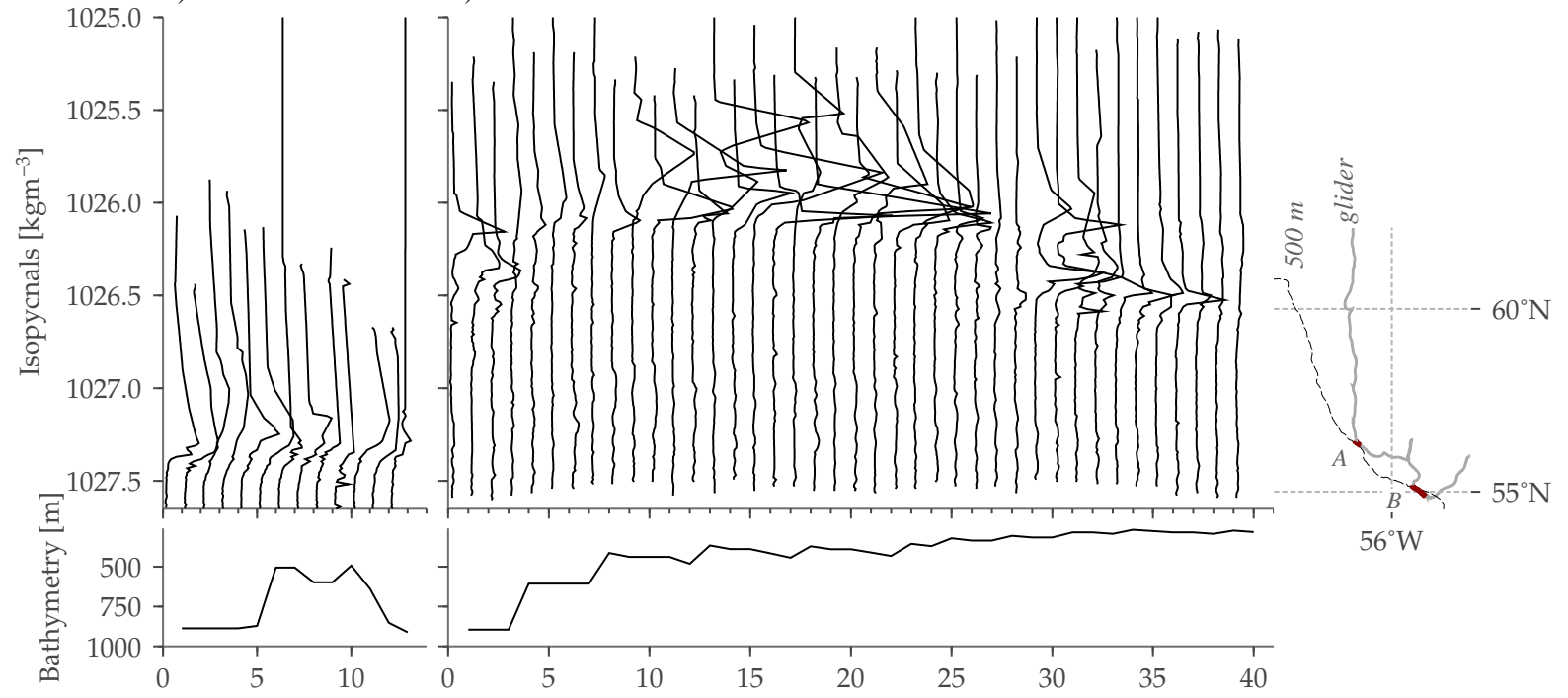

Figure 14: Fluorescence bloom intensity on isopycnals during the first shelf crossing (a) and second shelf crossing (b). The lower panels show the bottom depth beneath each glider profile. The inset map shows the glider track, the $500 \mathrm{~m}$ isobath and the two excursions onto the shelf. 

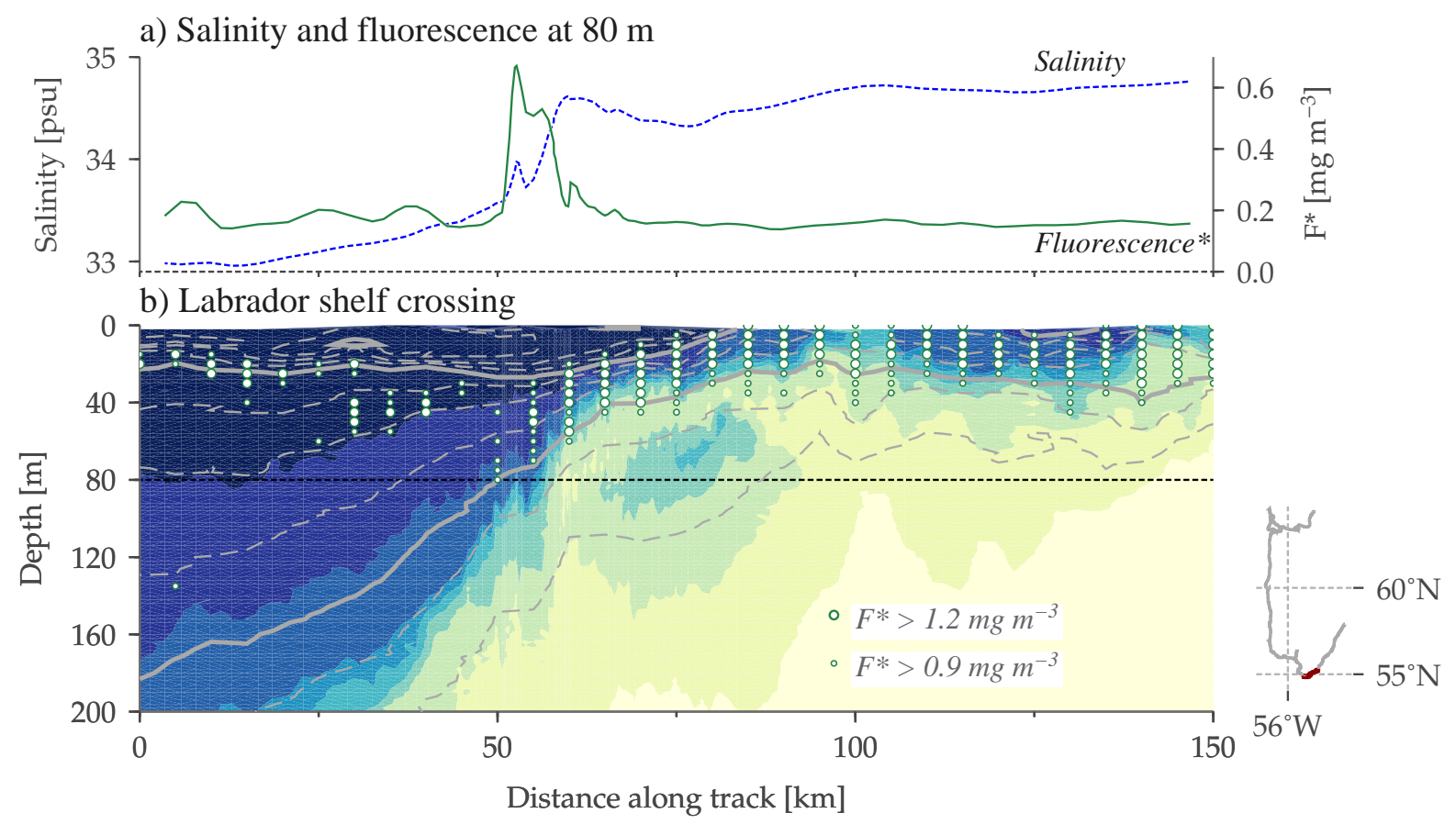

Figure 15: Salinity (shaded and solid line) and fluorescence bloom intensity (circles and dashed line) at the shelf break front. (a) The Labrador current is on the shelf, and very cold and fresh. Density contours of $1 \mathrm{~kg} \mathrm{~m}^{-3}$ (thick gray) and $0.25 \mathrm{~kg} \mathrm{~m}^{-3}$ (thin dashed gray) are marked. Fluorescence bloom intensity was gridded to $5 \mathrm{~km}$ along track and $5 \mathrm{~m}$ in depth for plotting purposes. Large circles indicate $\mathrm{F}^{*}>1.2 \mathrm{mg} \mathrm{m}^{-3}$; small circles indicate $\mathrm{F}^{*}>0.9 \mathrm{mg} \mathrm{m}^{-2}$. From $75 \mathrm{~m}$ along the track (1000 $\mathrm{m}$ water depth), $\mathrm{F}^{*}$ is in the surface $40 \mathrm{~m}$, while on the shelf (0-50 km along track), $\mathrm{F}^{*}$ is elevated in the thin layer at $20-30 \mathrm{~m}$ depth. At the front (50-75 km along track), high $\mathrm{F}^{*}$ to $80 \mathrm{~m}$ is observed on the X isopycnal, $34 \mathrm{psu}$ isohaline. (b) Line plot of salinity and $\mathrm{F}^{*}$ at $80 \mathrm{~m}$ depth shows the relative position of the front (high gradient in salinity) and peak fluorescence. 